Pavón Soldevila, I., Duque Espino, D. M., Sanabria Murillo, D. y Collado Giraldo, H. (2018): “La estela de 'Cabeza del Buey V/El Palacio' en el poblamiento de la Edad del Bronce de la sierra de Tiros (Badajoz)", Spal 27.1: 31-60. DOI: http://dx.doi.org/10.12795/spal.2018i27.02

\title{
LA ESTELA DE "CABEZA DEL BUEY V/EL PALACIO" EN EL POBLAMIENTO DE LA EDAD DEL BRONCE DE LA SIERRA DE TIROS (BADAJOZ)
}

\section{THE STELA OF “CABEZA DEL BUEY V/EL PALACIO" IN THE BRONZE AGE SETTLEMENT OF THE MOUNTAINS OF TIROS (BADAJOZ)}

\author{
IGNACIO PAVÓN SOLDEVILA \\ G. I. PRETAGU (Grupo de Estudios Prehistóricos Tajo-Guadiana), Área de Prehistoria, Universidad de Extremadura. \\ Correo-e: ipavon@unex.es ORCID: https://orcid.org/0000-0002-6130-6463 \\ DAVID M. DUQUE ESPINO \\ G. I. PRETAGU (Grupo de Estudios Prehistóricos Tajo-Guadiana), Área de Prehistoria, Universidad de Extremadura. \\ Correo-e: despino@unex.es. ORCID: https://orcid.org/0000-0002-6045-3031 \\ DIEGO SANABRIA MURILLO \\ Arqueólogo. \\ Correo-e: disanabria@yahoo.es. ORCID: https://orcid.org/0000-0002-8149-4270 \\ HIPÓLITO COLLADO GIRALDO \\ Instituto de Estudios Prehistóricos y Grupo do Quaternário e Pré-historia do Centro de Geociências da Universidade de Coimbra. \\ Correo-e: hipolitocollado@gmail.com. ORCID: https://orcid.org/0000-0003-4501-5671
}

Resumen: El objetivo de este trabajo es dar a conocer una nueva estela de guerrero recientemente recuperada en el término de Cabeza del Buey (Badajoz) y contextualizarla en el poblamiento de la Sierra de Tiros, un escenario de especial significación por su valor estratégico en las comunicaciones entre Córdoba y Badajoz. Así, tanto esta estela como otras ya conocidas en su entorno vienen a jalonar un espacio habitado en la prehistoria reciente, que cuenta con algunos asentamientos de la Edad del Bronce y un gran número de manifestaciones pictóricas que ponen de relieve su apropiación efectiva y simbólica a lo largo de un período cronológico amplio. Lejos de contemplarse esta estela en relación únicamente a sociedades ganaderas, se vincula a un modelo económico diverso, aunque de tintes agrarios.

Palabras clave: estelas del suroeste; Bronce Final atlántico; simbolismo guerrero; contexto mesoespacial; paisaje.

\begin{abstract}
The aim of this work is to discuss a warrior's stela, recently discovered in Cabeza del Buey (Badajoz) and to place it within the context of the mountain settlement of Tiros, a space of special significance for its strategic value in communications between Córdoba and Badajoz. This stela as well as others in the region mark an inhabited space in recent prehistory. The path along which the stela was discovered runs in proximity to Bronze Age settlements and several pictorial representations depicting both literal and symbolic appropriation across a large period of time. This particular stela will be considered in its relation to livestock communities, its links to a diverse economic model, and potential connotations for agrarian society at the time.
\end{abstract}

Keywords: Stela of south-west Iberia; Final Atlantic Bronze Age; warrior symbolism; semimicro-spatial context; landscape. 


\section{INTRODUCCIÓN}

La Sierra de Tiros (961 m s.n.m.) constituye una unidad de paisaje bien reconocible en el oriente badajocense. Se trata de una imponente sierra paleozoica sobresaliente entre otras tres unidades que definen su entorno peniaplanado, como son la extensa penillanura herbácea de La Serena (de sustrato esquisto-grauváquico) dispuesta al norte, y las penillanuras adehesadas del Arroyo de las Perillas (con idéntico sustrato) y Monterrubio de la Serena (de litología, sin embargo, granítica) que se sitúan al sur. Entre esta última población y las sierras de Benquerencia y Castuera -prolongación natural hacia occidente de la de Tiros, que al levante también tiene su continuación en las sierras de La Rinconada, La Osa y Las Vacas, junto a Cabeza del Bueyse extiende, por su parte, una superficie ligeramente deprimida ocupada por rañas (sustrato terciario-cuaternario) y dedicada hoy principalmente a cultivos (Servicio de Ordenación del Territorio del GOBEX 2015). Es, precisamente, la línea de sierras que discurre desde Castuera hasta Cabeza del Buey, el principal referente vigía tanto al norte, donde la extensa planicie alcanza hasta la línea del Guadiana y el Zújar, como al sur, donde discurre uno de los principales corredores de acceso natural desde el Medio Guadalquivir al Guadiana Medio, a través del norte de Córdoba (Pedroches). Pero la Sierra de Tiros atesora, además, otros importantes atractivos, como son toda una serie de puntos relacionados con las comunicaciones: los puertos de Mejará (o Mejoral, que la separa de la Sierra de Benquerencia), Almorchón (que la individualiza de las de la Rinconada y la Osa) y La Nava. Este último secciona la propia Sierra de Tiros y, a través del paisaje singular de Navacerrada, ofrece salida hacia el sur por el "camino de la Soriana", a través de las pedanías de La Nava y Helechal, por donde históricamente atravesaba la Cañada Real Soriana (Estepa 2000: 198). Olivares dispuestos en terrazas constituyen los únicos cultivos destacables del piedemonte, y en el monte propiamente dicho predomina el matorral; en tanto en las citadas penillanuras del complejo se dan cita algunas minas (plomo argentífero, cobre...) (fig. 1).

Este es, muy resumidamente, el marco vinculado a la estela de Cabeza del Buey V/El Palacio, que en este artículo estudiaremos. Aunque su hallazgo aconteció hace años, solo recientemente hemos tenido conocimiento de ella. Así, D. Juan González, vecino de Helechal (Badajoz), informó en mayo de 2016 a D. Jesús Fernández López, encargado del Centro de Interpretación de las Pinturas Rupestres de esta localidad (y gracias a cuya iniciativa pudo recuperarse), de su existencia. Aquel la había visto hace años en la finca El Palacio (Cabeza del Buey), sita al pie de la ladera norte de la Sierra de Tiros, sin reparar entonces en su importancia. Según contó, estaba amontonada en un majano, hoy situado junto a una gran encina, formado unos diez años atrás como consecuencia de la puesta en explotación como olivar intensivo de una parcela de ese paraje. En la primavera de 2016 -nos contó- ambos pudieron recogerla y la trasladaron al mencionado Centro, donde la reconocimos antes de que diéramos noticia de su existencia a la DGBMPC de la Junta de Extremadura, cuyos técnicos la depositaron días después al Museo Arqueológico Provincial de Badajoz. Finalmente, allí fue presentada y expuesta desde el mes de diciembre de ese año. El reconocimiento en dicha finca, por su parte, no deparó ningún dato significativo sobre el contexto arqueológico microespacial, al no apreciarse ni restos de estructuras ni otros materiales arqueológicos en el lugar del hallazgo.

\section{LA ESTELA DE CABEZA DEL BUEY V/EL PALACIO}

\subsection{Soporte y técnica decorativa}

El soporte sobre el que se elaboró esta estela es un bloque de piedra metamórfica del complejo esquistograuváquico y procedencia inequívocamente local, recolectada de entre los afloramientos más próximos de la penillanura herbácea de La Serena. No ofrece características singulares, salvo la disposición de un pequeño filón de cuarzo que cruza el tercio superior del soporte desde el sector superior derecho al inferior izquierdo. Esta grauvaca presenta unas dimensiones totales de $1,15 \mathrm{~m}$ de altura, $0,78 \mathrm{~m}$ de anchura y un espesor oscilante entre 0,11-0,13 m; y se encuentra fragmentada, por lo que su inclusión en el conjunto de soportes de entre 100-120 cm de altura, de los propuestos por Harrison (2004: 33) en su estudio sobre las estelas de guerrero -un grupo de altura intermedia-, tiene un valor relativo. Con las limitaciones indicadas, que sin embargo no impiden reconocer que nos ha llegado casi completo -si valoramos sobre todo la práctica integridad de su campo figurativo y en segundo plano la altura media $(1,20 \mathrm{~m})$ de los ejemplares recuperados en su zona (Celestino 2001: 82)-, el soporte no desentona formalmente de otros documentados en los valles del Guadiana y Zújar (la denominada "Zona III" por Celestino), e incluso en el Guadalquivir, personalizados por 

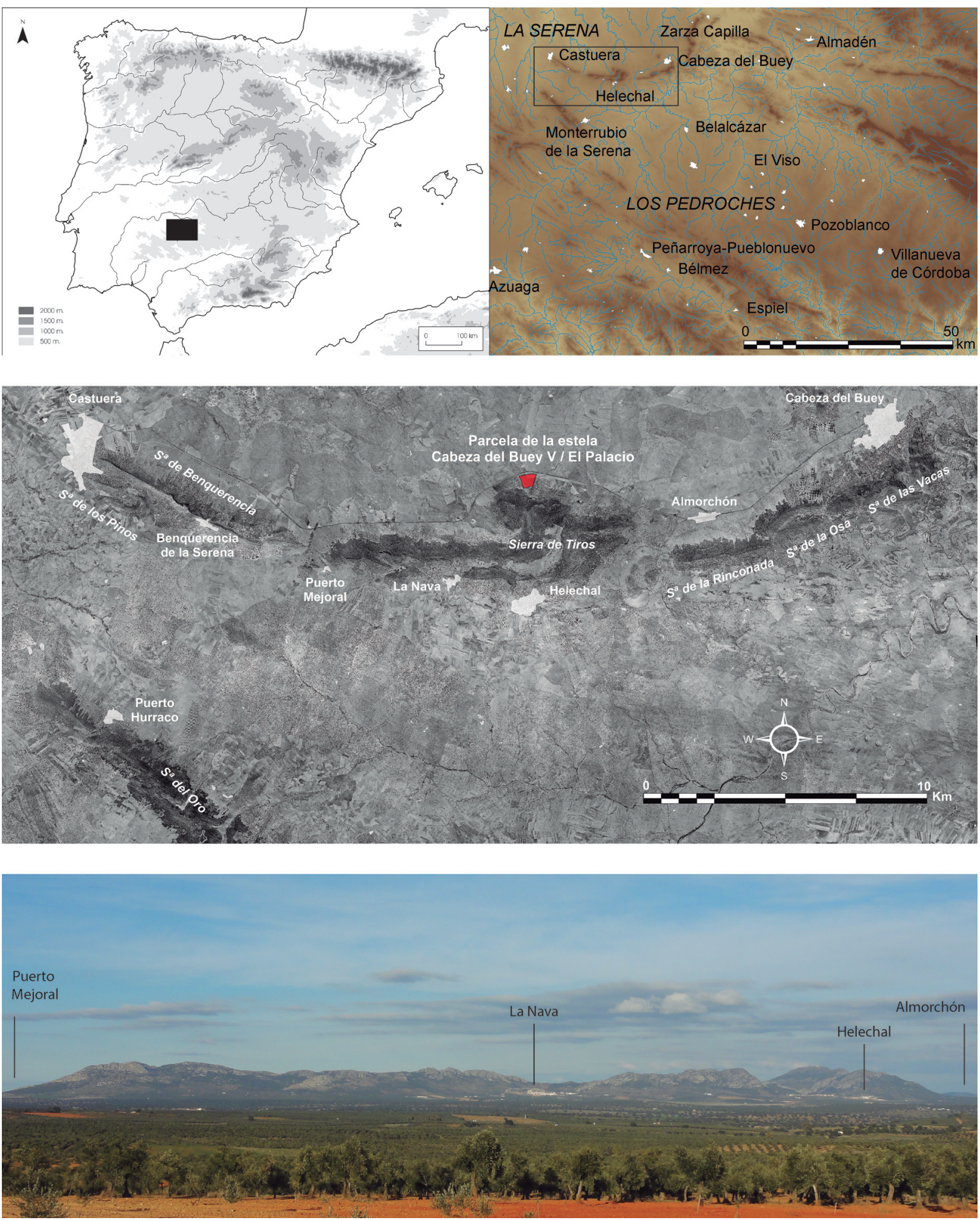

Figura. 1. Localización espacial de la estela de Cabeza del Buey V/El Palacio y panorámica de la Sierra de Tiros desde el suroeste. 
un característico formato cuadrado más o menos irregular, bien alejado de la figura esbelta de otras producciones (Celestino 2001: 81).

No se encuentra, sin embargo, excepcionalmente conservado; por el contrario, previamente a su proceso de documentación presentaba numerosas afecciones de musgo y líquenes, que una vez retirados evidenciaron una laja de superficie plana con rugosidades e irregularidades, afectada desigualmente y especialmente dañada en la parte superior y en la mitad inferior por el decapado antiguo de parte de su superficie, producido por causas naturales, y el salto de un fragmento de buenas dimensiones en el lateral derecho de la zona inferior (en todas nuestras descripciones empleamos estos términos desde el punto de vista de quien contempla la pieza frontalmente). Conocida es la tendencia a la exfoliación de algunos de los soportes empleados en la elaboración de estelas (en especial los esquistos) (Celestino 2001: 80). Sin embargo, el campo figurativo, en este caso, parece que ha quedado, excepto en los sectores ya apuntados, relativamente a salvo de dichos procesos erosivos. Este se ubica en la totalidad de la cara frontal de la estela; es decir, no existe un espacio proximal en reserva, libre de ornamentación, del que quepa deducir su condición de verdadera estela (disposición vertical), como sucede en otros ejemplares. En la cara posterior se han podido documentar hasta ocho cazoletas, hecho que, sin bien no es habitual, tampoco es absolutamente inédito en el conjunto de las estelas del suroeste, como demuestra el caso de La Vega/Córdoba 1 , aunque tales rasgos se valoren como modificaciones preexistentes del soporte que avalarían un proceso de reutilización de piezas dotadas de simbología previa (Celestino 2001: 435-436; Harrison 2004: 302-303; Díaz Guardamino 2010: 341) (fig. 2, A).

Desde el punto de vista de la técnica de elaboración, cabe indicar que se ha podido advertir el uso de dos modalidades complementarias, como son el piqueteado y la incisión; convivencia en modo alguno extraña en conjunto de las estelas extremeñas (Celestino 2001: 90-91). El piqueteado o percusión continua, efectuado tal vez con algún pico o martillo de piedra, se utilizó mayoritariamente, definiendo así todos los motivos grabados salvo uno, aplicándose en ocasiones de forma muy intensa, hasta conseguir rebajes muy marcados o amplios (como los que se aprecian en el tórax del antropomorfo de mayor tamaño, la cabeza del menor, el extremo del mango de uno de los espejos o, sobre todo, el umbo del escudo, que seguidamente describiremos). La incisión solo se empleó a la hora de trazar un ítem (que valoramos como un peine), curiosamente dispuesto sobre una llamativa veta de trazado rectilíneo y tonalidad algo más clara que el resto del soporte, que discurre en sentido diagonal al eje del campo figurativo.

\subsection{Composición escénica y elementos representados}

Creemos que el acercamiento a la composición escénica de esta estela resulta viable, dada la ya referida semi-integridad del campo figurativo. De esta forma, nuestro ejemplar puede integrarse sin reservas en el amplio conjunto que incluye a la figura humana masculina como tema principal -aludido sucesivamente como tipos IIC, IIC-D o "formato A" (Pingel 1974; Almagro Gorbea 1977, Gomes y Monteiro 1977 y Díaz-Guardamino 2010: 334 y 402)-; y más concretamente en el subconjunto de las estelas de guerreros con espada al cinto, bien reconocidas y caracterizadas sobre todo en los mencionados valles del Guadiana y Zújar, ocasionalmente en el Guadalquivir y excepcionalmente en el Tajo (Celestino 1990: fig. 13; 2001: 93 y 100). En todos esos casos -como sucede también en la pieza que ahora estudiamos- se ha abandonado la disposición canónica de las "estelas básicas" (lanza-escudo-espada) y un conjunto variable de elementos o personajes rodean o acompañan al antropomorfo principal. Así, en la estela de El Palacio pueden identificarse, además del antropomorfo con espada al cinto, una lanza (dispuesta horizontalmente en la parte superior), un escudo (a la derecha del guerrero), dos espejos, una fíbula (a la izquierda), un peine (a la derecha), un segundo antropomorfo de menor tamaño (a la derecha) y un carro (en la parte inferior), así como cuatro puntos o cazoletas (fig. 2, B).

\subsubsection{El antropomorfo con la espada al cinto}

En el subconjunto de las estelas de guerreros con espada al cinto pueden a su vez diferenciarse aquellos que llevan cascos de cuernos (o simplemente cuernos) -que resultan muy escasos, constatándose apenas los de Magacela (Fernández Oxea 1950: 300) y Montemayor (Ferrer 1999: 293-294)- de aquellos otros, mucho más numerosos aunque paradójicamente inéditos en el primer estudio general realizado sobre las estelas (Almagro Basch 1966), que no van tocados y que se documentan con particular concentración en la zona del Guadiana-Zújar. En este escenario, además de la pieza que en este estudio damos a conocer, se han catalogado 

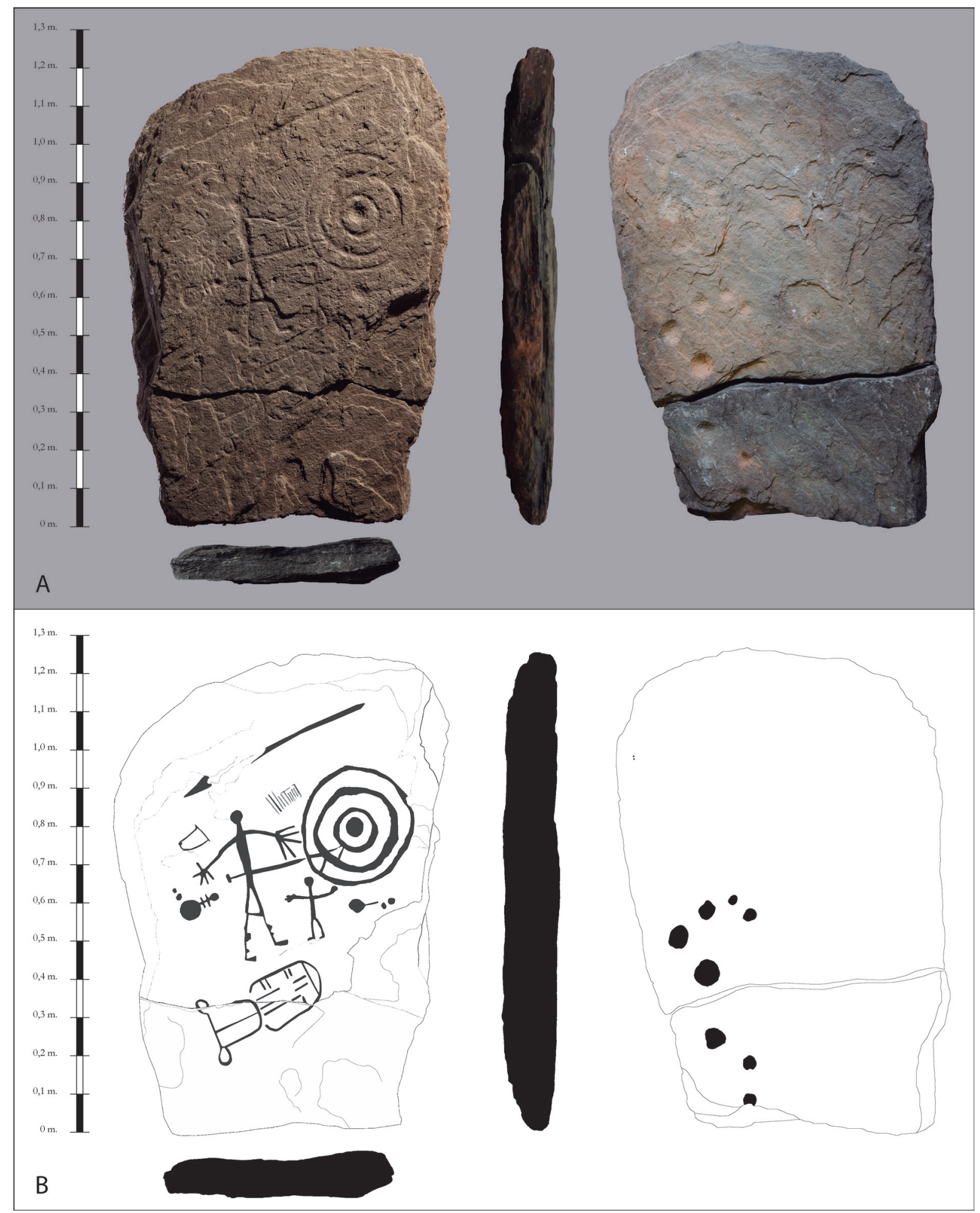

Figura 2. A) Fotografía y B) Calco de la estela de Cabeza del Buey V/El Palacio (cortesía del MAPB). 
ejemplares como los de Benquerencia de La Serena (Enríquez 1982a: 65-66), Cabeza del Buey II/La Yuntilla Alta (Almagro Gorbea 1977: lám. XIX-2), Cabeza del Buey III/El Corchito (Almagro Gorbea 1977: lám. XIX-3), Capilla II/Río Guadalmez (Enríquez y Celestino 1984: fig. 2a), Capilla IV/Vega de San Miguel (Celestino 2001: 376-377), Capilla VIII/La Pimienta (Domínguez et al. 2005: 50-51), Chillón/Llanos de los Roncos (Fernández y Zarzalejos 1994), Navalvillar de Pela/Cogolludo (Enríquez 1982b: 11-12), El Viso II/ Las Mangadas (Bendala et al. 1980: 383-385), El Viso III (Bendala et al. 1980: 385-387), El Viso IV/La Solanilla (Bendala et al. 1980: 387-389), La Bienvenida I (Murillo et al. 2005: 12-13), Olivenza/Monte Blanco (Bueno y Piñón 1985: 37), Orellana de la Sierra/La Atalaya (Domínguez et al. 2005: addenda), Herrera del Duque/Las Quinterías (Vaquerizo 1989: 32-38), Valdetorres I (Enríquez y Celestino 1984: 241-243), Zarza Capilla I/Los Llanos (Enríquez 1982a: 66-67); e incluso con iconografía idéntica pero grabada sobre soportes fijos, la Roca 8 de Arroyo Tamujoso (Domínguez y Aldecoa 2007: 351-352), que dan muestra de su particular éxito y significación. Sin embargo, también se han constatado con menor profusión antropomorfos con espada al cinto en el Guadalquivir - casos de Setefilla (Bonsor y Thouvenot 1928) y Torres Alocaz/Los Palacios (Oliva y Chasco 1976: 387)-, en el Tajo-Talavera de la Reina (Portela y Jiménez 1996)-, e incluso en el Sado -Ervidel II (Gomes y Monteiro 1977)-.

En este marco, el antropomorfo con espada al cinto de Cabeza del Buey V/El Palacio presenta una altura de $36,5 \mathrm{~cm}$ y un esquema muy sencillo pero sumamente personalizado: con los dos pies (sin que en ellos puedan diferenciarse los dedos) orientados hacia la derecha; las piernas rectilíneas unidas al tronco en una "V" invertida cerrada; los brazos dispuestos en una "V" invertida bastante abierta -a diferencia de la más habitual disposición en "U" invertida, que puede reconocerse en varios casos de los señalados más arriba- terminando en manos (la de la derecha algo desproporcionada) cuyos dedos, remarcados mediante el piqueteado simple, se muestran extendidos; un tórax no estrictamente lineal, sino con anchura ligeramente ascendente, que aparta a este antropomorfo del prototipo más esquemático (stick figures) identificado por Harrison (2004: 93); y una cabeza sin tocado resuelta de forma muy sencilla (fig. 3, A). Debemos señalar que el antropomorfo presenta también algunos elementos -recogidos en el calco que se exhibe junto a la pieza en el Museo Arqueológico Provincial de Badajoz (y que aquí reproducimos)- en nuestra opinión algo dudosos: sendos salientes delanteros a la altura de las pantorrillas y una línea recta, justo por encima de la altura de las rodillas, dispuesta horizontalmente de una pierna a la otra, que podría sugerir un faldellín. Nos cabe la duda de que pueda tratarse en ambos casos de procesos naturales que afectaron al soporte; pero, de aceptarse la factura antrópica de la línea que marca el reborde del mencionado faldellín, el mejor paralelo para el mismo sería posiblemente el que luce el antropomorfo de la estela de Herrera del Duque/Quinterías, aunque allí está conseguido mediante un rebaje (Celestino 2001: 406).

Como anticipábamos, el rasgo esencial del antropomorfo principal de la estela de Cabeza del Buey V/El Palacio es la disposición de una espada al cinto. Su trazado, con el extremo proximal a la izquierda y el distal hacia la derecha (que resulta mayoritario en el corpus de las estelas de guerreros sin tocado y con espada al cinto), sugiere su desenvainado y sujeción con la mano derecha. Más allá de ello, es bien conocido el esquematismo general que ofrecen las espadas al cinto representadas y las dificultades intrínsecas que ello supone de cara a la determinación tipológica y cronológica de tales armas, como la investigación ha señalado (Celestino 2001: 103-104). Peso a todo, autores como Brandherm (2007) no han rehuido su examen sistemático, proponiendo que los ejemplares al cinto son susceptibles de remitir hasta a 5 de sus 12 clases sistematizadas. De esta forma, los casos de espadas al cinto de los ejemplares antes mencionados se circunscribirían a sus clases D, H, K, L y M que -en particular las dos primerasremiten a diferentes tipos de espadas reales documentadas arqueológicamente (Brandherm 2007: láminas 38-41). Como sucede en muchos de estos casos, la disposición en la cintura del antropomorfo del ejemplar que ahora estudiamos dificulta precisar la morfología de la guarda de la espada, de manera que apenas podemos utilizar como únicos criterios de aproximación las formas del pomo y la hoja. La observación de ambos, sin embargo, creemos permitiría aproximar la espada de la estela de Cabeza del Buey V/El Palacio a las de la denominada clase $\mathrm{H}$ de Brandherm (2007: 143145), aunque con algún matiz. Así, pueden distinguirse un extremo proximal de la empuñadura que insinúa una forma de "T" -lo cual, creemos, resulta sugerente a nivel tipológico-y, ya en el tramo distal de la hoja, una pauta de adelgazamiento. Se trata de aspectos ambos presentes en la mencionada clase $\mathrm{H}$ y que podemos encontrar -hablando ya de ejemplares reales- en las espadas de "lengua de carpa" recuperadas principalmente en el hallazgo de la Ría de Huelva (Almagro Basch 1940; Brandherm 2007: 56-88). El matiz o 


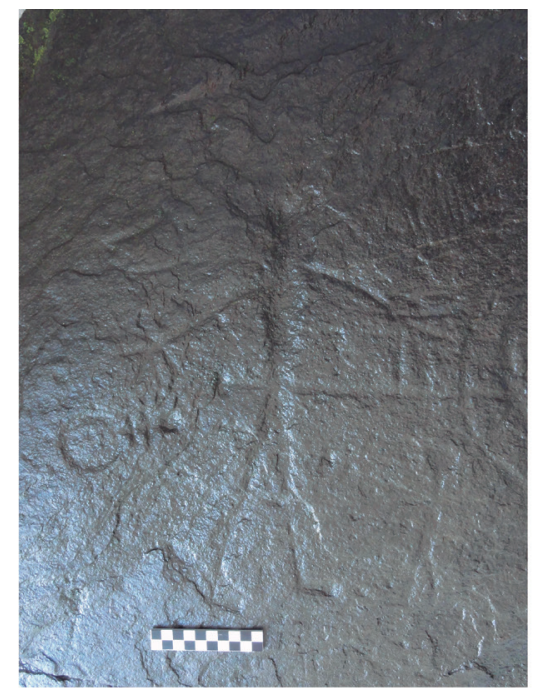

A

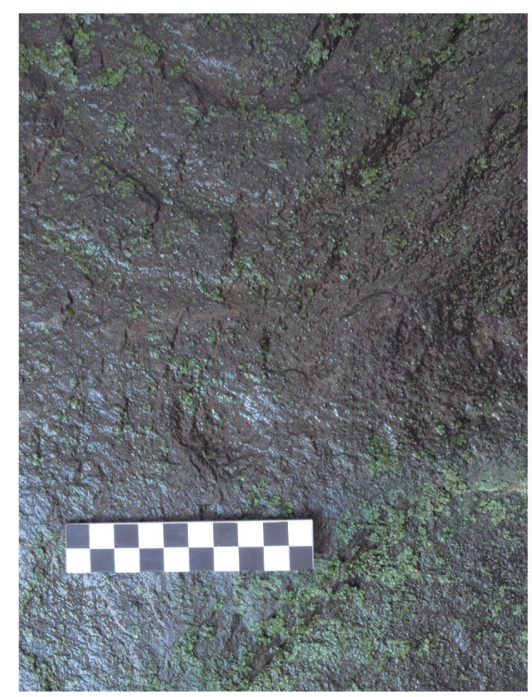

D

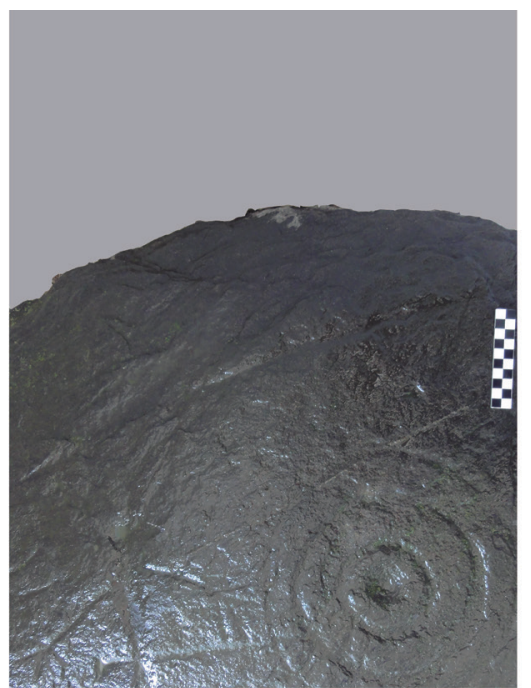

B

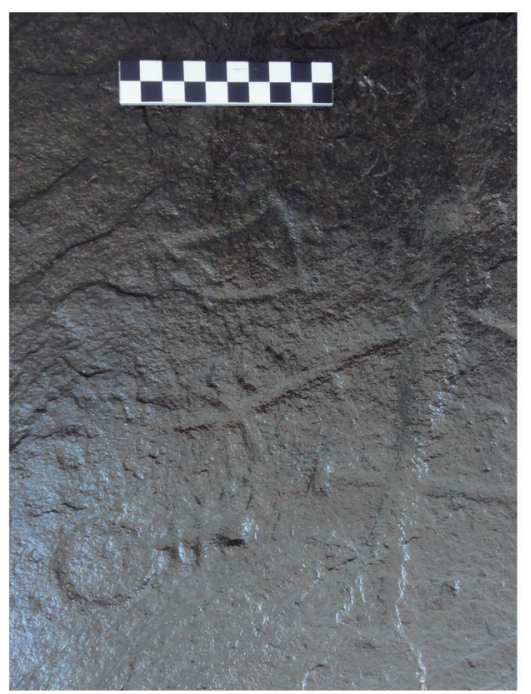

E

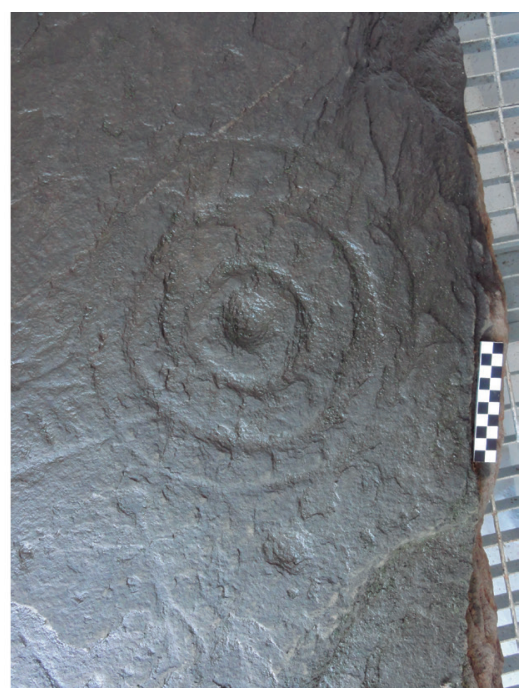

C

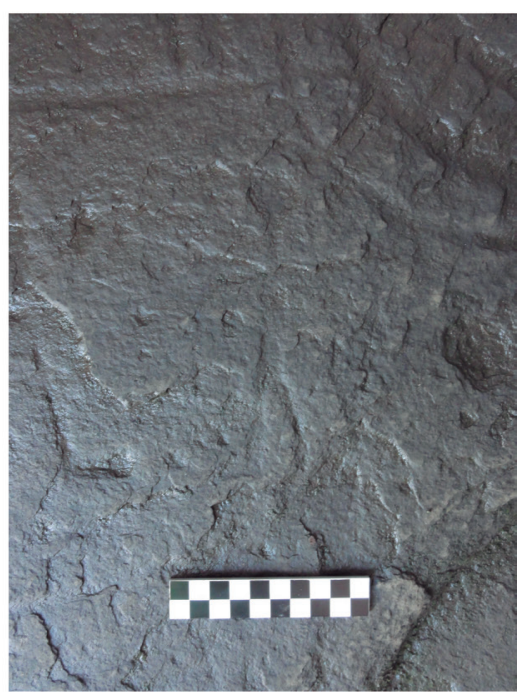

$\mathrm{F}$

Figura 3. Detalles de la estela de Cabeza del Buey V/El Palacio: A) Guerrero; B) Lanza; C) Escudo; D) Espejo 2; E) Fíbula; F) Antropomorfo 2.

diferencia respecto a la expresada clase $\mathrm{H}$ radica en que la estela que ahora estudiamos no representa la guarda - exageradamente plasmada en la mayoría de las estelas, según el propio Brandherm (2007: 145), respecto a los casos reales conocidos- por lo que la iconografía de esta espada se acerca a algunos ejemplares, como los de Los Palacios/Torres Alocaz y Cabeza del Buey II/ La Yuntilla Alta, integrados por su representación excesivamente esquemática en la clase L. Frente a ellas, sin embargo, la espada de Cabeza del Buey V/El Palacio sí que ofrece una hoja de lados paralelos y extremo distal en adelgazamiento que nos recuerda más bien a esos rasgos de las espadas de la Ría de Huelva. $\mathrm{Si}$, como creemos, nos encontramos ante una representación verosímilmente integrable en las espadas de lengüeta del tipo Huelva, cabría considerar la cronología propuesta para dicho tipo, 1050-930 cal a.C. (Brandherm 2007: 16), que últimamente se hace extensible hasta comienzos del siglo IX (Brandherm y Moskal del Hoyo 2014). Se trata de una referencia a la hora de fechar la estela de Cabeza del Buey V/El Palacio, independientemente de proponer su inclusión en el horizonte del Bronce Final IIIA de la secuencia atlántica, sito a un nivel más general dentro del Bronce Final II 
de la secuencia poblacional registrada en Extremadura (Pavón 1998a; 1999: 200-201). Cabe añadir que a una tipología grosso modo comparable se han vinculado algunos ejemplares representados en las estelas, entre ellos los de Alamillo (Celestino 2001: 104 y 392-393), Cabeza del Buey III/El Corchito, Chillón/Llanos de los Roncos -todos, como los del caso que ahora damos a conocer, ubicados en el valle del Zújar-, así como la no muy alejada representación de la estela de Cancho Roano (Brandherm 2007: 143-144). Por otra parte, del entorno del castillo de Almorchón (Cabeza del Buey) procede, al parecer, una espada inédita (integrada hoy en la Colección Martínez de la Mata) de ese mismo tipo que nos hablaría de su familiaridad en la comarca. De la simple observación de la fotografía difundida en internet de dicho ejemplar (IES Muñoz Torrero 2017) -en que pueden observarse una lengüeta rematada en cola de pez algo deformada, calados tanto en esta como en la guarda, recazos marcados y una hoja con nervio central flanqueado por acanaladuras- se desprende, con todas reservas, su más que probable pertenencia a la serie evolucionada del tipo Huelva, o serie III de Brandherm (2007: 59, lám. XVII no 89-90), aunque solo un examen directo de la pieza, a la que no hemos tenido acceso, permitiría corroborarlo.

\subsubsection{La lanza y el escudo}

Se tratan, junto a la espada, de los otros dos elementos característicos de las "estelas básicas" que, sin embargo, perviven en bastantes de las estelas con antropomorfo. Así, además del caso en estudio, y restringiéndonos al subconjunto de guerreros sin tocado y con espada al cinto, podemos identificarlos a ambos, sin dudas, en muchos de los ejemplares ya mencionados, como los de Benquerencia de La Serena, Cabeza del Buey II/La Yuntilla Alta, Capilla VIII/La Pimienta, Navalvillar de Pela/Cogolludo, El Viso II/Las Mangadas, El Viso IV/La Solanilla, La Bienvenida I, Orellana de la Sierra/La Atalaya, Valdetorres I, Zarza Capilla I/ Los Llanos; la Roca 8 de Arroyo Tamujoso y tal vez Capilla IV/Vega de San Miguel. Si bien, por tanto, la asociación global de tales temas es muy abundante, el análisis de los detalles de ambos ítems en el ejemplar de Cabeza del Buey V/El Palacio restringe mucho más, como veremos, el círculo de paralelos. No tanto por la lanza en cuestión, que presenta una longitud de poco más de $50 \mathrm{~cm}$ y, como suele ser habitual entre las representadas en las estelas (Celestino 2001: 101-102), adolece de rasgos tipológicos definidos: apenas podemos constatar un largo astil y la hoja terminada en punta hacia la izquierda; ambos parcialmente afectados por la mala conservación del soporte y con trazo impreciso, a base de piqueteado o rebaje total, y por tanto sin mucho margen para unos detalles que su autor no se preocupó de reflejar (fig. 3, B).

El escudo, por su parte, sí que ofrece más ingredientes para el análisis y la singularización de esta pieza (fig. 3, C). En esencia, el que ahora nos ocupa consiste en un escudo redondo en el que se grabaron mediante piqueteado hasta tres círculos concéntricos y en él resulta perfectamente discernible un umbo central conseguido mediante un marcado rebaje y, con más dificultad, sendas escotaduras en "V" observables en los dos círculos intermedio y exterior. Dichos rasgos permiten incluir este ejemplar en los tipos IE de Celestino (2001: 119-121) y IC de Harrison (2004: 127): escudo tipo Herzsprung con umbo central y sin asidero en "I". Aunque los escudos en escotadura en "U/V", o tipo Herzsprung, resultan muy habitualmente plasmados en las estelas de Gata, Montánchez, e incluso el Guadiana-Zújar, los de este subtipo particular con umbo -identificado en las estelas de Almargen, El Viso IV/La Solanilla, Toya/Peal de Becerro, Boux I, Boux II, Figueira, Ervidel II y Luna- apenas están presentes en los ejemplares del Suroeste, donde podría verse en los de Zarza Capilla I/Los Llanos y Navalvillar de Pela/Cogolludo (Celestino 2001: 120); en este último, incluso, mostrando el mismo esquematismo en la representación de la escotadura que se aprecia en nuestro caso o en otros, como sucede en la estela de Toya/Peal de Becerro (Celestino 2001: 414). Desde una perspectiva sensible a la composición, nuestro escudo se situó a la derecha (es decir, junto al brazo izquierdo del guerrero, con el que debía sujetarse) y con un tamaño (27 $\mathrm{cm}$ de diámetro) proporcionalmente mayor que el de su portador. En opinión de Celestino (1990: 57), el escudo - cuyo simbolismo a nadie escapa, dada su proliferación sobre estos soportes- es el elemento que mejor refleja la evolución formal, compositiva y geográfica de las estelas; si bien el hecho de desconocerse escudos reales en la península ibérica, posiblemente por haberse fabricado en materiales perecederos (Celestino 2001: $150)$, resta posibilidades de contrastación a las inferencias que los solo grabados, aunque a veces muy detalladamente, sugieren. Es bien conocida, en cualquier caso, la adscripción al Bronce Atlántico de los escudos con escotadura en "V", para los que, en función de las dataciones proporcionadas por los moldes de madera de arce de Kilmahamogue (Con Antrim) y Cloonlara (Co Mayo), puede proponerse que el tipo era conocido, al 
menos en Irlanda, en un momento anterior a $c 1132$ cal a.C. (Díaz-Guardamino 2010: 348), si bien estudios recientes, reconociendo la complejidad del problema, no descartan incluso una cronología aún más antigua (Uckelmann 2011 y 2012; Needham et al. 2012: 487).

\subsubsection{Los objetos de prestigio}

Cinco son los objetos de prestigio que podemos observar en la estela de Cabeza del Buey V/El Palacio: dos espejos, la fíbula, el carro y el peine. Se trata de algunos de los elementos adicionales que -salvo el carro- a veces aparecen junto a las armas en las estelas de formato básico (en ese orden de frecuencia cuantitativa) (Celestino 2001: 164-165, 167 y 195); pero que más habitualmente se integran en las composiciones donde está presente el antropomorfo. Restringiéndonos al subgrupo de los guerreros sin tocado y con espada al cinto, los cuatro elementos asociados solo están presentes en la estela de Cabeza del Buey II/La Yuntilla Alta; en tanto los demás ejemplares conocidos presentan abundantemente espejos, en menor medida carros,

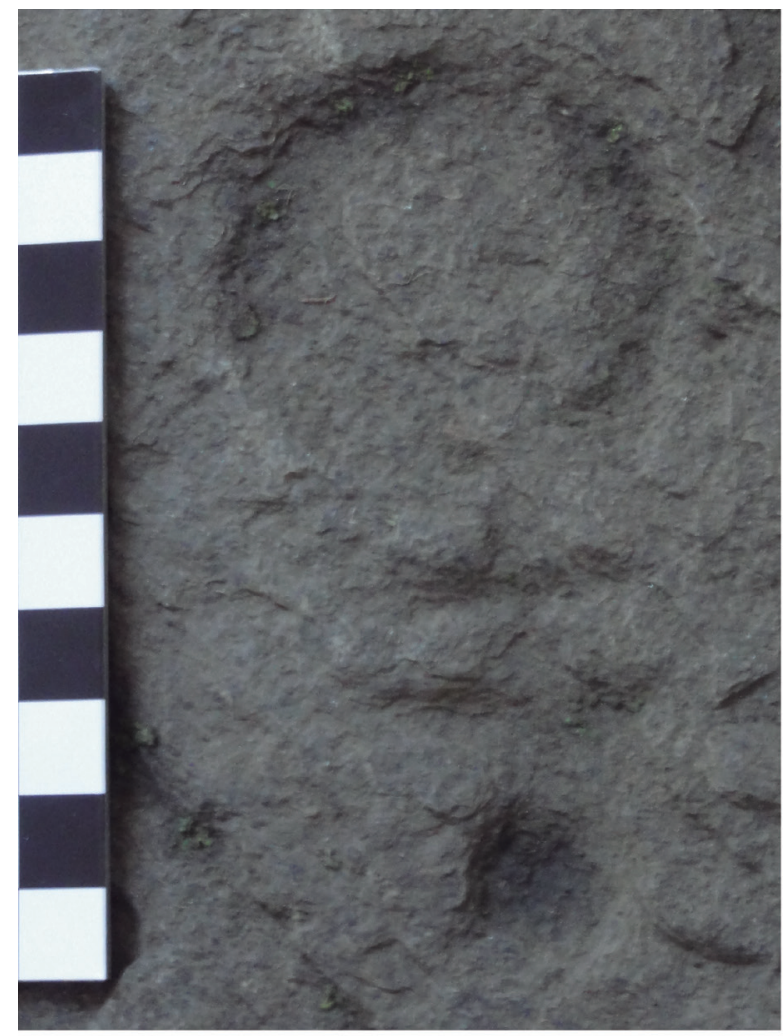

A ocasionalmente peines y solo puntualmente fíbulas, aunque en el caso de este último objeto no siempre resulta clara y aceptada su identificación.

El primero de los espejos grabados en la estela que ahora presentamos, con una longitud total de $10,5 \mathrm{~cm}$, consta de un mango bastante elaborado y un sencillo disco redondo cuyo diámetro alcanza $5,5 \mathrm{~cm}$. Se sitúa junto a la mano derecha del guerrero, aproximadamente en el espacio central izquierdo del soporte, si lo observamos de frente, como algunos otros documentados en esta zona geográfica (Celestino 2001: 166). Más allá de ello, ofrece algunos rasgos técnicos y morfológicos que son susceptibles de mayor comentario. Así, la técnica empleada para su elaboración fue la del piqueteado, realizando un rebaje completo de la cazoleta, como es práctica general entre los espejos de las zonas del Guadiana-Zújar y Guadalquivir; es decir, haciendo uso de una modalidad de talla evolucionada y presumiblemente moderna desde la perspectiva evolutiva defendida por Celestino (2001: 164-165). Los rasgos morfológicos que de su observación se derivan nos parecen también muy sugerentes, si los comparamos con los espejos hasta hoy conocidos (fig. 4, A).

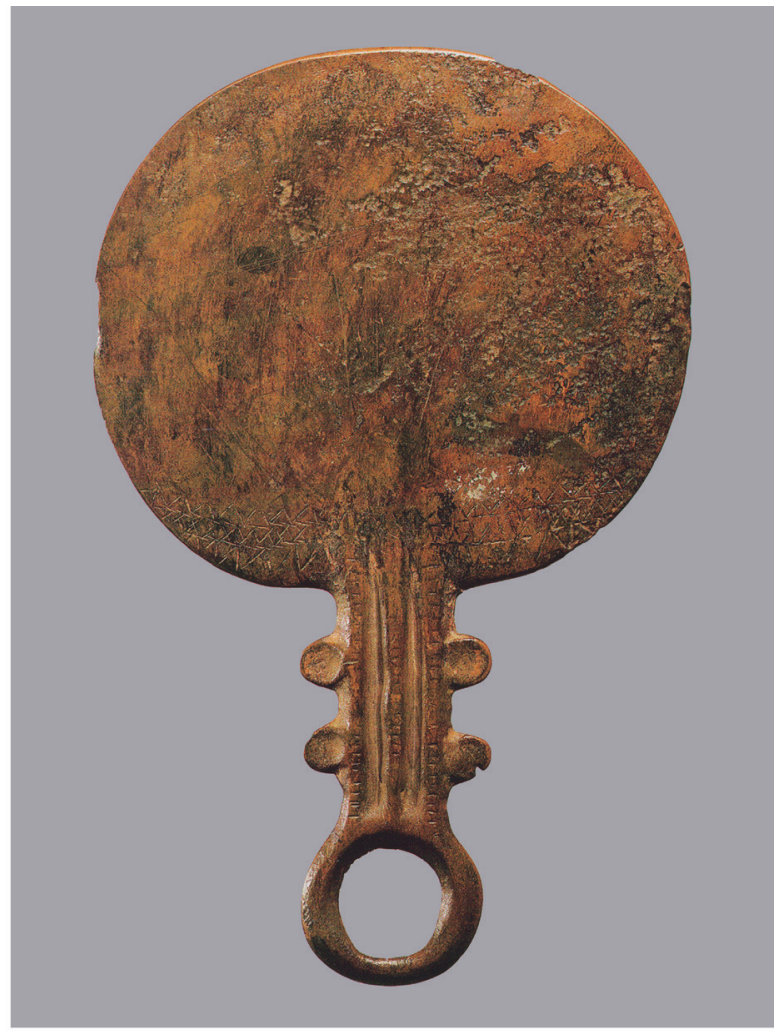

B

Figura 4. A) Espejo 1 de la estela de Cabeza del Buey V/El Palacio; B) Espejo de morfología similar (Anlen y Padiou 1989: 361). 
Así, los especialistas han distinguido de ordinario entre los espejos simples (con una luna ovalada o circular de la que sale un trazo recto a modo de mango), presentes en Gata, el Tajo y el Guadiana-Zújar, o en el segundo ejemplar de esta misma estela; y aquellos otros, más elaborados (con un travesaño que separa la cazoleta del mango, decoraciones de borlas o remates claramente observables en los mangos), presentes tanto en el Guadiana-Zújar como en el Guadalquivir (Celestino 1990: fig. 12; Harrison 2004: 153). Sin embargo, el mango del espejo representado en la estela de Cabeza del Buey V/El Palacio, que conceptualmente se acerca más a los segundos, ofrece rasgos singulares aunque muy poco prácticos, como los dos travesaños colocados en el tramo central del mismo, que, bastante inconvenientes para ejercer una prensión cómoda, completan la ornamentación con un remate circular. Tipológicamente, existen referencias de espejos reales de concepción aproximada al aquí representado, como el elaborado en Grecia y amortizado en un contexto escita fechado en el siglo VII a.C. (Anlen y Padiou 1989: 360-361) (fig. 4, B). De esta forma, el resultado final grabado es un modelo más bien extraño y escasamente funcional, acaso resultado de evocar cierto tipo de espejos complejos, pero sobre los que tal vez no se tenía en ese contexto espacio-temporal un conocimiento solvente ni un uso habitual. El segundo espejo (fig. 3, D), el de tipo simple, de esta estela se ubica bajo el escudo y a la derecha de un segundo antropomorfo - del que enseguida hablaremos- guardando una cierta simetría en la disposición de la escena, refrendada por la aparición de dos cazoletas tanto junto al primer como al segundo espejo: cazoletas-espejo complejo-antropomorfo mayor / antropomorfo pequeño-espejo simple-cazoletas. Díaz-Guardamino (2010: 351 y 354-355) ha recordado no hace mucho la ausencia de referentes (espejos recuperados en contextos arqueológicos del Bronce Final) en la península ibérica a partir de los que sugerir una fecha para los espejos de las estelas, proponiendo a partir de otros extrapeninsulares su conocimiento al menos desde el 1000 a.C.

El segundo elemento de prestigio presente en la estela que ahora nos ocupa es una posible fíbula grabada sin mucho detalle justo por encima del brazo derecho del guerrero (fig. 3, E). Si bien sus dimensiones son discretas (aproximadamente unos 6,5 $\mathrm{cm}$ de ancho y unos $4 \mathrm{~cm}$ de altura), está sobredimensionada en relación a la escala de este. Como sucediera con los espejos, son varios los ejemplares de estelas del subtipo de guerrero sin tocado y con espada al cinto que según algunos autores representan dicho ítem, aunque en muchos de ellos se haya cuestionado su identificación (Díaz-Guardamino 2010: fichas de catálogo 174, 264, 268, 346, 353). En su conocido estudio, Celestino determinó sin embargo un relativamente amplio elenco de posibles tipos representados en las estelas: de arco y de antenas (ambos en el Tajo), de codo (en Tajo y Guadiana-Zújar), rectangular (en el Guadiana-Zújar) y de puente curvo (en el Guadiana-Zújar y Guadalquivir); señalando la mayor abundancia de las fíbulas de codo (Celestino 2001: 187 y 207). Dicho tipo ha sido reestudiado no hace mucho por M. Torres (2012: 462-464) y Díaz-Guardamino (2010: 350), quien ha ponderado que está presente en poco más del $10 \%$ de las piezas conocidas y subrayado que pese a ello, su valoración en un análisis cronológico de las estelas es importante, dado que en la mayoría de casos su representación es detallada; línea seguida igualmente por Mederos y Jiménez (2016). Precisamente creemos que, con todas las prevenciones que impone la mala conservación del soporte y su esquemático trazo, la estela de Cabeza del Buey V/El Palacio nos sitúa ante otra posible representación de fíbula de codo. Las referencias materiales hasta hoy conocidas en la península ibérica tienden a circunscribirse con bastante precisión las fíbulas de codo al 1050-930 cal a.C., con base en el hallazgo de la Ría de Huelva; si bien los hallazgos del Cerro de la Miel (Zafayona, Granada), con fecha del s. XII cal a.C. -objeto de alguna polémica-, abren la posibilidad a su origen en momentos más tempranos, hoy por hoy no compartida por otros investigadores (Díaz-Guardamino 2010: 399).

El carro, como sucede en varios casos documentados donde también tiende a diferenciarse espacialmente, ocupa el campo inferior de la estela que ahora estudiamos, presentando una longitud máxima -subordinada de nuevo a la deficiente conservación del soporte, en particular en su extremo inferior derecha- de en torno a $28 \mathrm{~cm}$. Entre las estelas integradas en el mismo subgrupo que la de Cabeza del Buey V/El Palacio, los carros están presentes en un buen número: Cabeza del Buey II/La Yuntilla Alta, El Viso IV/La Solanilla (en ambos se representa en un lateral) El Viso II/Las Mangadas (donde se graba en la parte superior de la escena), Olivenza/Monte Blanco, Orellana de la Sierra/La Atalaya y Zarza Capilla I/Los Llanos (en las tres ocasiones abajo). Por otra parte, también aparecen representados en un $37 \%$ de los soportes catalogados en la zona del Guadiana-Zújar por el estudio de Celestino, en que se caracterizan por un alto grado de esquematismo. Si bien este autor desiste de cualquier ensayo tipológico por causa de la gran homogeneidad 


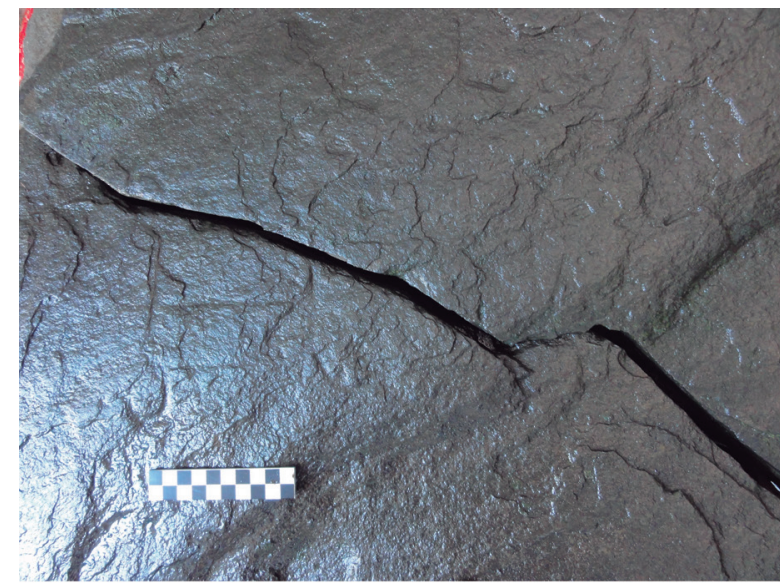

A

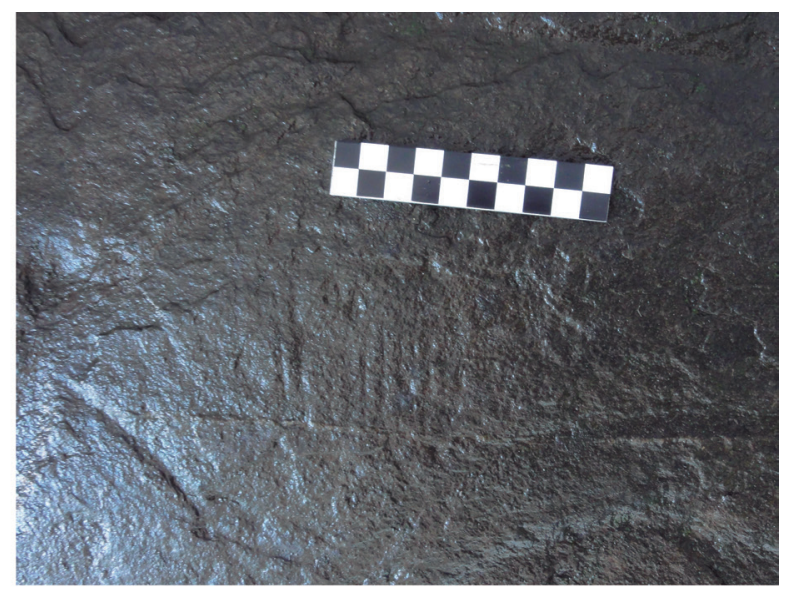

B

Figura 5. Detalles de la estela de Cabeza del Buey V/El Palacio: A) Carro; B) Peine.

formal que presenta el ítem en el corpus de las estelas de guerrero (donde aparece plasmado no de una forma realista, sino conceptual), no es menos cierto que a la par subraya la personalidad de los ejemplares del Guadiana-Zújar, con dos grandes asideros en la parte posterior del armazón, aspecto liriforme muy irregular en su visión general cenital y ruedas radiadas o de aspecto macizo (Celestino 2001: 216). En este marco, el nuevo ejemplar de Cabeza del Buey V/El Palacio ofrece elementos claramente identificables en el patrón comarcal, como los grandes asideros posteriores o un timón que se nos muestra prácticamente corrido desde el fondo de la caja; pero también extraños rasgos singulares susceptibles de comentario: así, no aparecen representadas las dos ruedas que muestran todos los carros conocidos, ni su eje. Aunque cabe la posibilidad de que hoy no se observen tales elementos por efecto de la deficiente conservación de este sector del soporte, ello nos parece poco probable (fig. 5, A). Más bien nos inclinamos a pensar que estamos ante una figura inconclusa, como se ha sugerido también para carros de las estelas de Olivenza/Monte Blanco y Cabeza del Buey II/La Yuntilla Alta, donde se constatan ejemplares incompletos (aunque en ambas ocasiones se documenta un segundo carro ya íntegro, cosa que no sucede aquí). Cabe indicar que dos lanzas corren paralelas al timón desde la zona anterior de la caja, detalle que se observa en otros ejemplares, como los cercanos carros de las estelas de Cabeza del Buey II/La Yuntilla Alta, Zarza Capilla I/Los Llanos, El Viso II/Las Mangadas y El Viso IV/La Solanilla, o los de Valencia de Alcántara I, Capote/Higuera la Real, Écija V/El Berraco, Ategua y, tal vez, Zarza Capilla III/Dehesa Boyal (Harrison 2004: 147). Por otra parte, las patas de los animales de tiro, que unen sus cabezas formando un arco continuo más allá del trazo recto que en esta ocasión alude a la pieza para uncirlos, no se observan con nitidez en el situado en la parte inferior (animal derecho). De no admitirse su carácter inacabado, habría que reconocer que, más allá del estado de conservación, estuviésemos ante una visión muy sinóptica del carro, extrema incluso en la pauta de esquematización sugerida para las estelas de esta zona; que ofrece un proceso similar, aunque con sus singularidades, en el arte esquemático regional (Collado 2015). No son factores, todos ellos, que ayuden a proponer paralelos morfológicos y derivadas cronológicas para el presente carro. Tradicionalmente, no obstante, se ha reconocido que los ejemplos arqueológicos reales peninsulares datan ya de época orientalizante; planteándose referentes más antiguos del Mediterráneo para explicar el origen de las representaciones locales (Bendala 1977: 185; Celestino 1985: 51; 2001: 224229; Quesada 2005: 47; Mederos 2008) y admitiéndose que con la evidencia disponible no es posible remontar con seguridad la presencia de carros en las estelas a un momento anterior a mediados del s. XII cal a.C. (DíazGuardamino 2010: 354), fechándose estos muy posiblemente en una horquilla IX-VII a.C. en cronologías sin calibrar (Quesada 2005: 47). Más que con carros de funcionalidad estrictamente bélica, se tiende a apostar hoy por su carácter simbólico, por sus connotaciones en el tránsito al Más Allá o su relación con el espíritu aristocrático de las élites del Bronce Final-Hierro I peninsular (Quesada 2005: 48). 
Siguiendo esta misma tendencia al esquematismo aludida a propósito del carro, podemos referirnos al posible peine -pues menos probable nos parece su identificación con un calcofón, como a veces se ha propuesto para ítems similares (Celestino 2001: 176)- grabado en la nueva estela de Cabeza del Buey. Sabida es la disponibilidad de este elemento en una tercera parte de las documentadas en el entono Guadiana-Zújar -según el estudio general de Celestino (2001: 166)- y su ubicación bien alejado del centro escénico o junto a la cabeza del guerrero, como aquí sucede. En el subgrupo tipológico del guerrero con espada al cinto y sin tocado, observamos peines en los ejemplares de Cabeza del Buey II/La Yuntilla Alta, Cabeza del Buey III/El Corchito, Chillón/Llano de los Roncos y Ervidel; si bien el mejor paralelo técnico-morfológico del peine grabado ahora en estudio se encuentra en el de Esparragosa de Lares III/Las Bodeguillas (Pavón y Duque 2010: 118-120; fig. 5-e). Como sucede en ese otro caso, el de Cabeza del Buey V/El Palacio está realizado con una técnica diferente al resto de los grabados, empleando la incisión en lugar del piqueteado. Aprovecha, además, una veta de color algo más claro en la roca para remarcar el límite inferior del peine, que en sí está definido, con trazos muy someros, por una docena de púas verticales que salen de un cuerpo horizontal marcado por una línea igualmente incisa (fig. 5, B). La mayoría de los autores defienden, con base en materiales peninsulares aunque de probable origen oriental, una cronología para los peines en el tránsito Bronce Final-Orientalizante, aventurándose a circunscribir su desarrollo en torno al 1000-900 cal a.C. (Díaz-Guardamino, 2010: 351 ), en un momento ya avanzado del fenómeno de las estelas, que se conjuga bien tanto con su técnica a veces diferente de elaboración, como con su adición postrera a los otros motivos previamente grabados.

\subsubsection{El personaje secundario}

Debemos añadir que sobre la superficie de la estela hemos documentado además la existencia de un segundo antropomorfo. Este se nos presenta en un tamaño menor (16 cm de altura) al del guerrero ya comentado y sin la espada, adoptando una postura similar a la de aquel, con los brazos extendidos, aunque enfrentado en función de la posición de los pies hacia la izquierda (fig. $3, \mathrm{~F}$ ). Tanto las contrastadas escalas en que se expresan como la diferente complejidad de los espejos a que se asocian, y la ausencia/presencia de espada al cinto, entre otros factores, constituyen la plasmación gráfica de un principio de diferenciación y tal vez un concepto de jerarquía ya señalado por otros autores. Entre ellos, posiblemente sea Harrison el más elocuente, al conceder cierta relevancia al hecho y diferenciar incluso las composiciones (figuras antropomorfas pareadas en jerarquía) presididas por esta idea: El Viso IV/La Solanilla, Carmona/Haza de Villaos, Burguillos/La Nea, Los Palacios/Torres Alocaz y Ervidel II (Harrison 2004: 101); a las que sumamos hace algún tiempo la de Esparragosa de Lares III/Las Bodeguillas, señalando la conveniencia de incluir en el mismo grupo a las de Guadálmez y Cortijo de la Reina I (Pavón y Duque 2010: 120). No es nuestro objetivo entrar en la discusión sobre si representan formas incipientes de patronazgo/clientela o formas emergentes de poder adscrito a través de la herencia (Mederos y Harrison 1986; Ruiz Rodríguez 1996; García Sanjuán 1999: 86-87), sino más bien sugerir su carácter polisémico y admitir la enorme dificultad de acceder a su último significado.

\section{LA ESTELA DE CABEZA DEL BUEY V/EL PALACIO EN LA ARQUEOLOGÍA PREHISTÓRICA DE LA SIERRA DE TIROS}

La prehistoria de la Sierra de Tiros viene siendo desde hace años objeto de la atención de diversos investigadores, sobre todo a partir de la definición de un importante conjunto de pinturas rupestres esquemáticas en torno a Helechal (Martínez Perelló 1995). Ocupando estas manifestaciones un lugar sin duda sobresaliente, no se deben pasar por alto de cara a una valoración integral del poblamiento los asentamientos prehistóricos, que empiezan a atisbarse a través de algunas series de materiales recuperados en superficie, cada vez más numerosos, y que se suman a diversos hallazgos aislados (como son los bronces, los oros o las propias estelas) adscritos a esta sierra o a sus inmediaciones.

\subsection{Las pinturas rupestres esquemáticas de Helechal}

Las manifestaciones pictóricas rupestres de Helechal forman parte del conjunto de abrigos pintados extremeños que se extienden, de suroeste a nordeste, entre las sierras de Castuera y la Moraleja, y se integran de una forma más amplia en el importante y personalizado núcleo de La Serena, con más de un centenar de enclaves catalogados (Martínez Perelló 1999). No obstante, sus 
dinámicas generales de evolución temática, técnica y tipológica entroncan con las generalmente observadas en el arte rupestre postpaleolítico regional (Collado y García 2010 y 2013; Collado et al. 2014). Restringiéndonos al espacio serrano entre Castuera y Cabeza del Buey (fig. 6), se han documentado hasta el momento unos 36 enclaves de tipología muy variada (grandes oquedades, abrigos de escasa profundidad, estrechas grietas entre farallones verticales, etc.) que en su mayor parte albergan paneles claramente orientados hacia el espectador, dispuesto a una altura media de un metro desde el nivel del suelo actual de los abrigos, y ocupando superficies de muy diversos tamaños. En ellos, por regla general, no se advierten elementos escenográficos o criterios compositivos claros, sino una reiterada yuxtaposición de motivos diversos sobre las superficies seleccionadas, cuyo uso gráfico varía desde paneles con un escaso aprovechamiento pictórico de la superficie disponible hasta auténticos palimpsestos densamente poblados de motivos superpuestos, de gran interés para determinar su evolución diacrónica.
Si atendemos a su temática, las figuras simbólicas son mayoritarias (con una presencia destacada de series horizontales de barras verticales en paralelo, muy variadas en cuanto al número de motivos que la componen), aunque notable es también la presencia de motivos tectiformes o placas y trazos ondulados; constatándose en proporciones menores las series de puntuaciones, ramiformes, figuras solares, trazos grafitados o simples manchas de pigmento sin forma definida. Los antropomorfos, por su parte, son minoritarios, con tipologías de tendencia claramente esquemática (ancoriformes simples, figuras en "Y", cruciformes o esquemas en "T"), acompañados por algunos grupos de figuras bitriangulares antropomorfizadas mediante la representación de las extremidades (generalmente los brazos). Las figuras de animales son igualmente escasas y limitadas, salvo contadas excepciones (como el ciervo de la Cueva de los Vencejos), a formatos pectiniformes de pequeños tamaños y ejecutados en trazo fino. Es necesario señalar, finalmente, la significativa presencia de pequeñas representaciones de ídolos oculados con

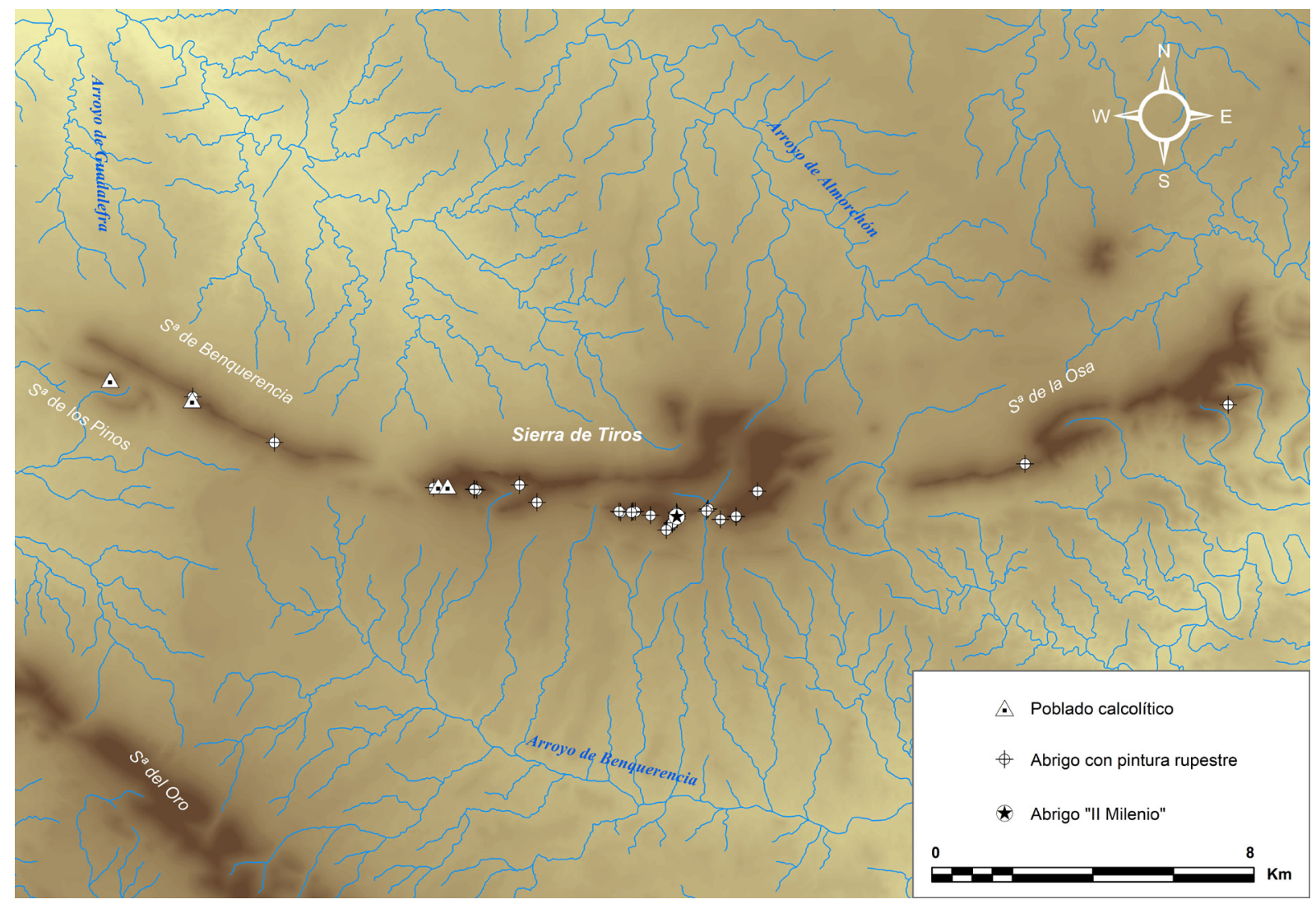

Figura 6. Distribución de abrigos con pintura rupestre esquemática y poblamiento calcolítico en las sierras entre Castuera y Cabeza del Buey. 
tatuaje facial, sugerentes a la hora de contribuir a un encuadre crono-cultural para este conjunto figurativo; así como otros motivos, que en su momento describiremos, directamente relacionado con la iconografía habitual en las estelas de guerreros.

El color predominante en todo este horizonte figurativo es el rojo, con una infinidad de matices que van desde las tonalidades más oscuras a las anaranjadas. Si bien esta variedad de matices depende de una amplia serie de factores, por regla general prevalecen los tonos de rojo más oscuros (en algunos casos incluso granate). En una proporción mucho menor, aparecen motivos pintados con pigmentos de tonalidad grisácea o negruzca, así como otros de color blanco o beige asociados a motivos que -como veremos más adelantepertenecen a las etapas más avanzadas de la secuencia figurativa. Por su parte, la técnica empleada es muy simple, constatándose mayoritariamente motivos ejecutados con trazos lineales de grosores diversos y perfiles que en algunos casos resultan especialmente irregulares, lo que posiblemente tenga su origen en el empleo de algún tipo de instrumento de punta blanda para aplicar el pigmento (fibras vegetales, pelo de animal, pequeños tampones de tela, etc.), cuya textura debió ser bastante diluida y con un escaso grado de viscosidad. El amplio rango de grosores que han sido documentados (desde 1-2 mm, hasta $2 \mathrm{~cm}$ o más) no hace sino confirmar el uso de un instrumental variado, aunque los casos en donde una misma figura agrupa diversos tipos de trazo son excepcionales. Solo esporádicamente se ha registrado el uso de la tinta plana para rellenar algunos contornos. En conexión directa con la técnica y el tipo de trazo empleado, hemos de analizar el tamaño de las representaciones. Este es igualmente variado, aunque, siguiendo la tónica general de la pintura rupestre esquemática regional, se ha detectado una tendencia sistemática que coloca los motivos de mayor tamaño (a veces con alturas superiores a los $30 \mathrm{~cm}$ ) en las etapas iniciales de este ciclo pictórico; reduciéndose progresivamente hasta el final de la serie (donde encontramos los esquemas de menor tamaño, cuya altura no llega a superar 1,5 cm).

Esta evolución técnica y figurativa se desarrolla en un amplio margen diacrónico cuya fase inicial se remonta a un horizonte neolítico medio-final, constatado recientemente por uno de nosotros (H.C.G.) en los sondeos arqueológicos practicados en las cuevas de Los Pinos y Los Vencejos (ambos en La Nava), para el proyecto de investigación Los contextos del arte rupestre esquemático en la provincia de Badajoz. Por el momento desconocemos la entidad y características del poblamiento en dicho horizonte, pues los citados yacimientos corresponden a ocupaciones esporádicas vinculadas acaso a la explotación de los recursos subsistenciales básicos que ofrece el territorio (caza, recolección, fuentes de agua) y que serían apropiados simbólicamente mediante un registro gráfico predefinido desde sus orígenes. Dicho registro estaría particularmente caracterizado por figuras rojas de mediano y gran tamaño dispuestas sobre paneles con escasa densidad figurativa y en los que predominan las barras, puntuaciones, motivos solares, figuras antropomorfas, trazos ondulados y algunas representaciones zoomorfas que aún ofrecen características seminaturalistas más propias de etapas precedentes (Collado 2006).

A dicha fase inicial sigue un estadio expansivo que puede adscribirse a la Edad del Cobre. En él se multiplica el número de enclaves, bien reutilizando los antiguos abrigos, bien ocupando gráficamente nuevos espacios. Es posible que todo ello esté vinculado con un proceso de estructuración y control del territorio, apreciable en la globalidad del poblamiento regional. En dicho estadio el arte rupestre muestra una mayor diversidad técnica (especialmente referida al tipo de trazos empleados), el uso de nuevas variedades cromáticas y una progresiva disminución en el tamaño de las representaciones. Los paneles se hacen más complejos, en la mayor parte de las veces por una mera yuxtaposición figurativa, aunque en no pocas ocasiones comienzan a advertirse estructuraciones de tendencia vertical o piramidal. El discurso gráfico mantiene, no obstante, las iconografías precedentes, a las que se van incorporando nuevos elementos como los tectiformes complejos, los ídolos oculados con tatuaje facial o los motivos bitriangulares antropomorfizados.

Particular interés, a los efectos de este trabajo, tiene la constatación, ya en una fase final de recesión de la pintura rupestre esquemática, de nuevos elementos simbólicos que guardan relación directa con los habitualmente asociados al mundo de las estelas de guerreros. Nos referimos, en particular, a la figura humana documentada en panel 8 del abrigo "II Milenio" (Helechal) (fig. 7, A-B), que aparece tocada con un casco. Esta representación, cuya altura alcanza solo unos 8 $\mathrm{cm}$, muestra claramente unas extremidades superiores e inferiores insertadas al tronco a semejanza de una "U" invertida, que, en caso de las piernas, se completan con la indicación del pie y de sus dedos, a modo de tres ramificaciones especialmente apreciables en el izquierdo. Se representa igualmente el falo, que también aparece, si bien no muy asiduamente, en las estelas, como sucede en los casos de El Viso I, Aldea del 


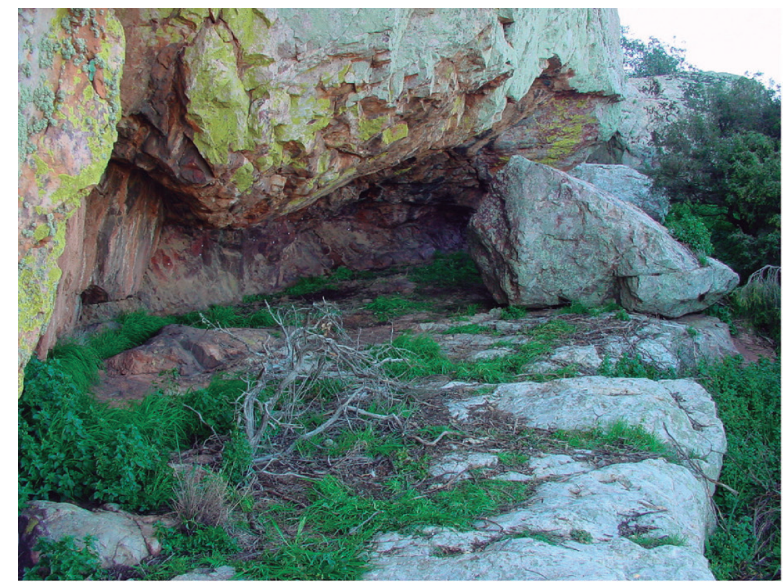

A

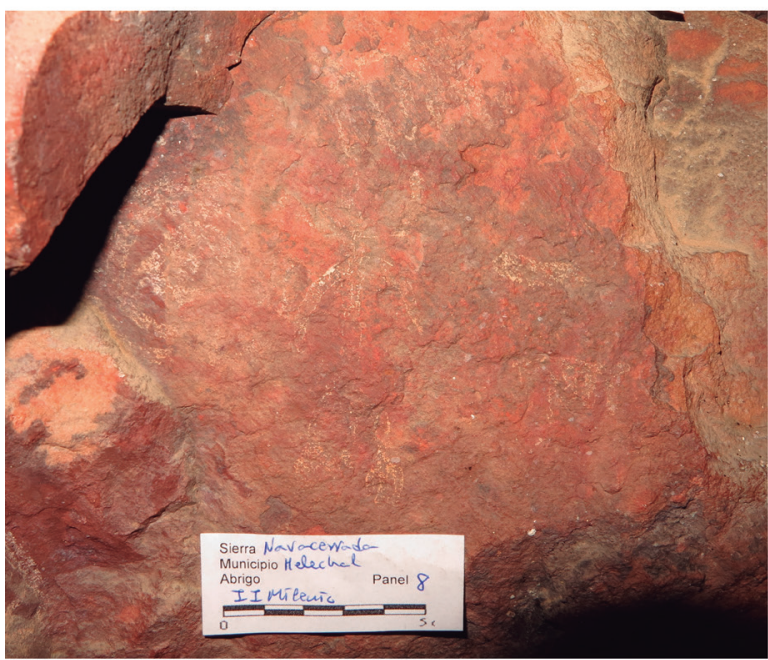

C

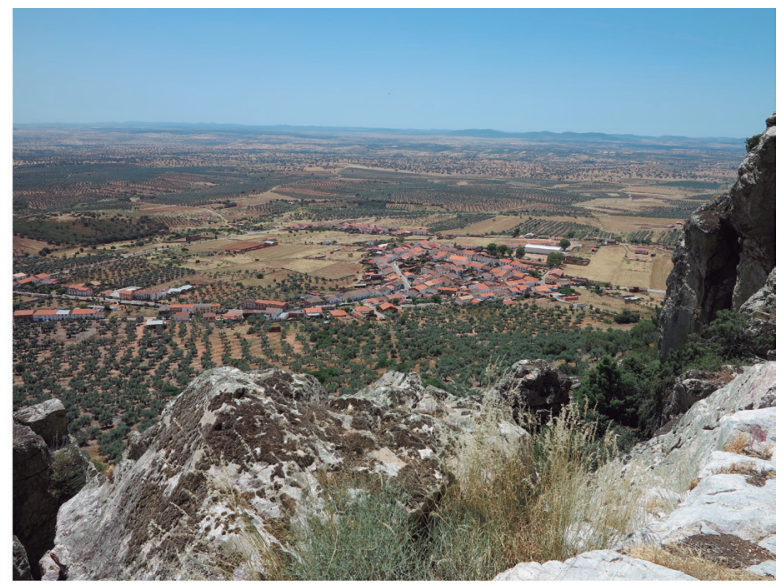

B

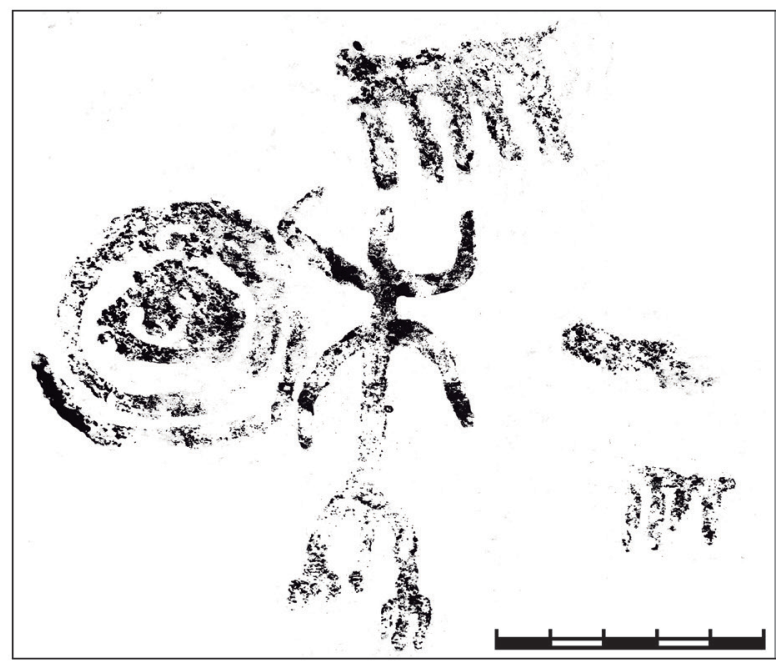

$\mathrm{D}$

Figura 7. A) Abrigo "II Milenio"; B) Vista desde el abrigo; C) Panel 8 del abrigo "II Milenio" (Helechal); D) Calco de los motivos elaborados con pigmentos blancos o beiges.

Rey III, Ategua, Ervidel II, Cerro Muriano I y Las Bodeguillas (Pavón y Duque 2010: 116). El tocado con que se cubre puede identificarse no sin con ciertos problemas con un casco de cuernos, cuya proliferación en las estelas es de sobras conocida.

El antropomorfo está acompañado, además, por un escudo circular representado a su derecha. Este tiene un diámetro de unos $5 \mathrm{~cm}$ y muestra una iconografía consistente en tres círculos concéntricos y un punto central que podría interpretarse como su umbo (fig. 7, C-D). Se trataría, en todo caso, de una composición sumamente esquemática, que conecta con algunas de las representaciones más sinópticas de este elemento en las estelas, particularmente constatadas en el valle del Zújar, y que recordaría a los escudos del tipo IId definido por Celestino (2001: 122) en las estelas. De este tipo, escudos sin escotadura ni abrazadera pero con círculos concéntricos y umbo, se han advertido varias representaciones en estelas no muy alejadas, como las de Cogolludo y Orellana de la Sierra (Domínguez et al. 2005, addenda), El Viso III (Bendala et al. 1980: 385-387, fig. 3) y, tal vez, Capilla VII (Díaz-Guardamino 2010: catálogo, 273); así como sobre soportes fijos, caso de la roca 8 de Arroyo Tamujoso (Domínguez y Aldecoa 2007: lám. LI).

Ambas figuras, antropomorfo y escudo, que están plasmadas haciendo uso de los pigmentos blancos o beiges antes mencionados, parecen estar acompañadas de otras en esos mismos tonos: un pectiniforme situado sobre ellos y algunos restos más de difícil interpretación 
en la parte inferior del panel. Más allá de ello, las representaciones del abrigo "II Milenio" poseen además dos singularidades: la primera, que permite ampliar el registro de soportes fijos con motivos vinculados al mundo de las estelas (Collado 2016: 9-10) -que se suman a los grabados ya conocidos en La Serena (Domínguez y Aldecoa 2007), Espejo (Córdoba) (Murillo et al. 2005: 22), con más dudas Logrosán (Cáceres) (Rodríguez et al. 2015), y a algunos otros enclaves del Tajo portugués (Gomes 1989: figs. 21 y 24; Brandherm 2007: 25)-; la segunda, su ubicación en los límites del poblado posiblemente más representativo, como veremos a continuación, de la Sierra de Tiros.

\subsection{Los poblados de la prehistoria reciente-protohistoria}

En la Sierra de Tiros y su entorno inmediato se viene constatando desde hace un tiempo un intenso poblamiento de la prehistoria reciente. Aunque por el momento no se ha abordado ninguna prospección sistemática, sí que, al menos en su cara sur, se han realizado algunas tareas de reconocimiento que han posibilitado tomar un primer contacto con asentamientos que ofrecen un cierto potencial. Alguno de ellos, como El Montón, ya fue dado a conocer hace algunos años; pero otros, que seguidamente mencionaremos, permiten ir definiendo un panorama progresivamente más complejo e interesante para la contextualización de la estela objeto de este estudio. No obstante, ninguno de ellos ha sido objeto de ningún tipo de sondeo o excavación arqueológica, por lo que obviamente se impone cautela a la hora de valorarlos.

El mencionado Cerro del Montón, considerado como un gran poblado en alto (con cumbre a $860 \mathrm{~m}$ s.n.m.) (fig. 8, A), se conocía a partir del mencionado estudio de M. ${ }^{a}$ I. Martínez Perelló, que, en función de una muestra abundante de materiales de superficie, propuso una adscripción amplia del Calcolítico al Bronce Final. Incluía tal colección cerámicas casi exclusivamente elaboradas a mano consistentes en fuentes, vasos de paredes rectas y de perfil en $\mathrm{S}$, así como cuencos de borde exvasado, de casquete esférico o de carenas medias y altas. También se constataron cazuelas carenadas que resultaron determinantes para fundamentar dicha adscripción (Martínez Perelló 1995: 225-233). Recientemente se han recogido algunas otras piezas más, tanto lisas como decoradas, que vienen a refrendar, en general, esa valoración y particularmente su desarrollo durante la Edad del Bronce. En este sentido, podrían destacarse algunos vasos de carena baja-media muy marcada y magníficos acabados bruñidos, característicos del Bronce Pleno del Suroeste, que en tierras badajocenses tienen por el momento en el Cerro del Castillo de Alange su más conocida expresión (Pavón 1998b: 82). Igualmente, se documentan varios fragmentos con decoraciones incisas e impresas con motivos de espigas, con características análogas a las de las cerámicas de Protocogotas y Cogotas I, y asimilables a las documentadas en otros asentamientos del Bronce Pleno avanzado y Tardío del sur de Extremadura (Cerro del Castillo de Alange, El Carrascalejo) (Pavón 1998b: 84; Pavón y Duque 2014: 66; Enríquez y Drake 2007) y Medio-Bajo Guadalquivir (Llanete de los Moros, Carmona, la Mesa de Setefilla, etc.) (Abarquero 2005: 186-205). También de este enclave procede algún fragmento de posible cazuela con carena alta y muy marcada, similar a las del tipo A.I.a que viene considerándose tradicionalmente característico de la fase prefenicia del Bronce Final en el Bajo Guadalquivir (Ruiz Mata 1995: 286-287). De allí mismo procede un fragmento de vaso elaborado en piedra (¿alabastro?) que constituiría sin duda una pieza singular (fig. 9). Igualmente, tenemos noticia de la aparición en este mismo enclave de una placa de bronce mal conservada, pero en la que resultan reconocibles motivos vegetales orientalizantes, en poder de un particular de Helechal. Si bien no hemos podido valorar con precisión las dimensiones del asentamiento, por las reticencias de los propietarios a acceder al mismo para tal fin, cabe estimarlo como un poblado de proporciones notables, de en torno a 8 ha, posiblemente acorde al valor geoestratégico de su posición. Así, el Montón dispone de una visibilidad extraordinaria hacia el sur y hacia el valle interior de Navacerrada (y al final de este, el Puerto de La Nava), que controla directamente. Desde el alto del Montón a la ya aludida representación pictórica del abrigo "II Milenio" hay tan solo $200 \mathrm{~m}$ en línea recta, situándose de hecho esta hacia el límite oriental del asentamiento, a cuyos pies discurre uno de los pocos caminos que conectan Navacerrada con el sur.

Otro asentamiento representativo de la Edad del Bronce -aunque no puede descartarse una ocupación anterior, acaso calcolítica- es el del Castillo de la Nava (fig. 8, B). Se trata de una ocupación en ladera, posiblemente facilitada por estructuras de acondicionamiento en terrazas que ocasionalmente se intuyen en la topografía del sitio, que también alcanza a la cima, muy modificada por la posterior ocupación islámica. Su altitud es de en torno a 835 m s.n.m. y la extensión total que permiten calcular los hallazgos de superficie asciende 


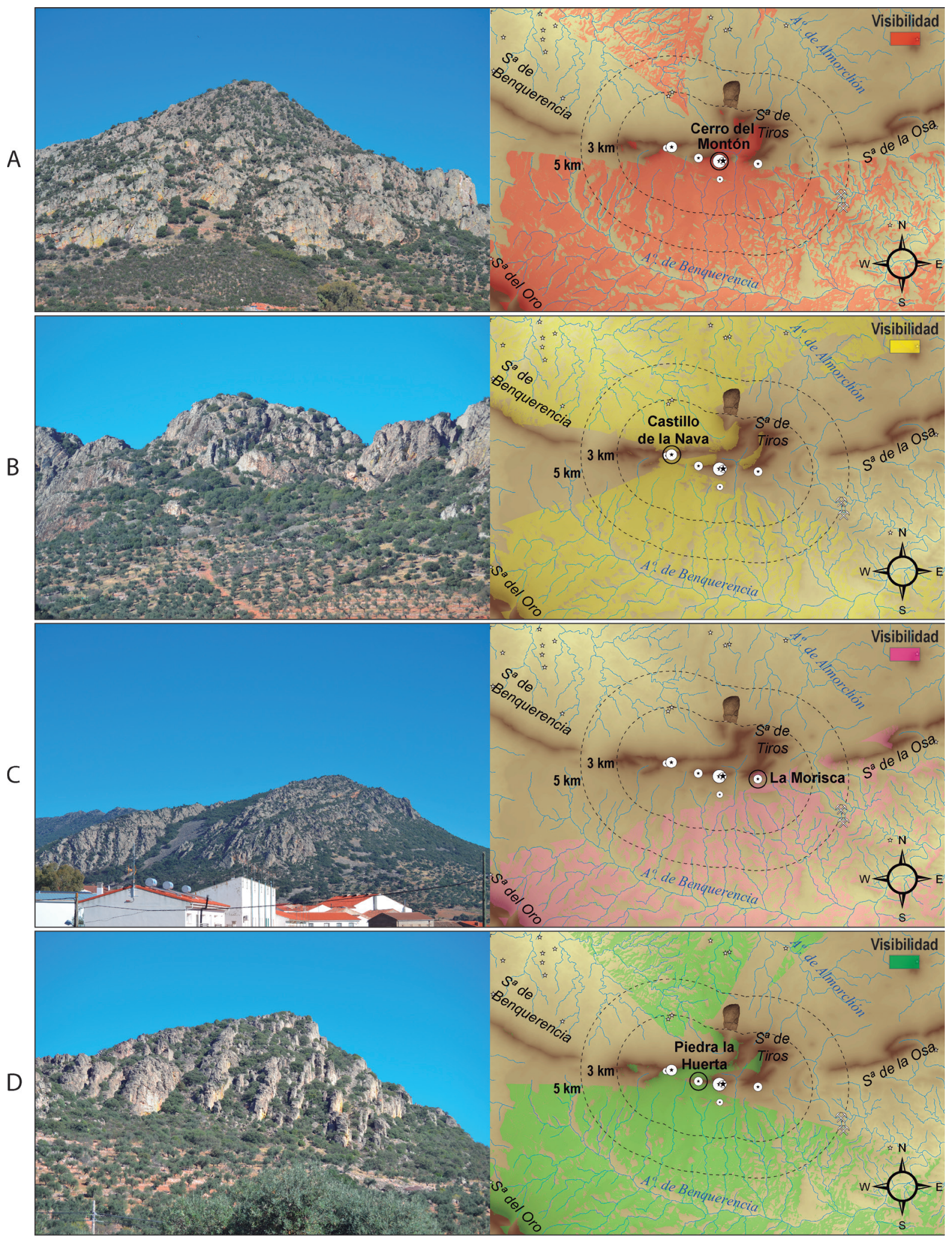

Figura 8. Asentamientos de la Edad del Bronce en la Sierra de Tiros y sus visibilidades: A) El Montón; B) Castillo de la Nava; C) La Morisca; D) Piedra la Huerta.

ISSN: $1133-4525$ ISSN-e: $2255-3924$ 


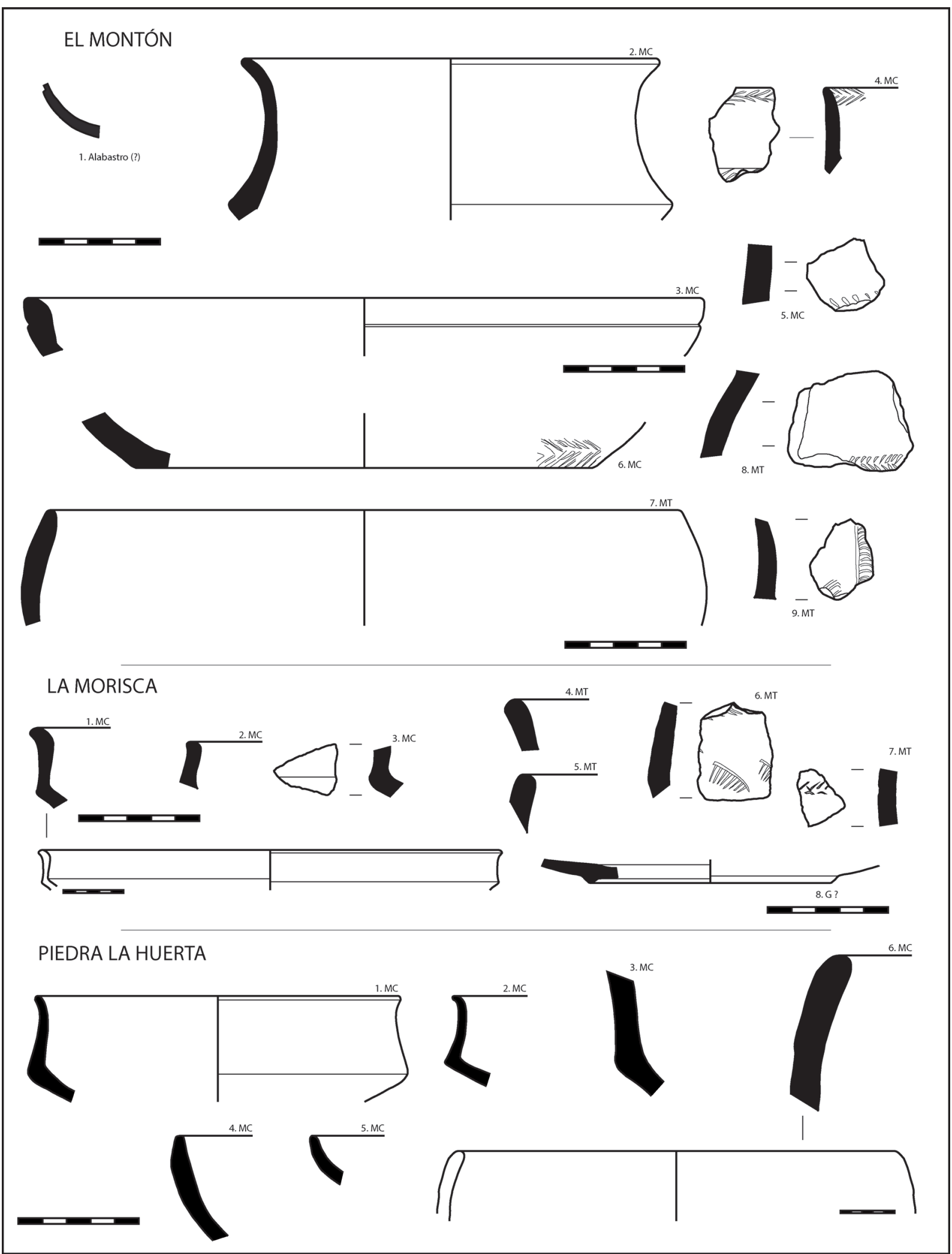

Figura 9. Materiales de superficie de El Montón, La Morisca y Piedra la Huerta. 


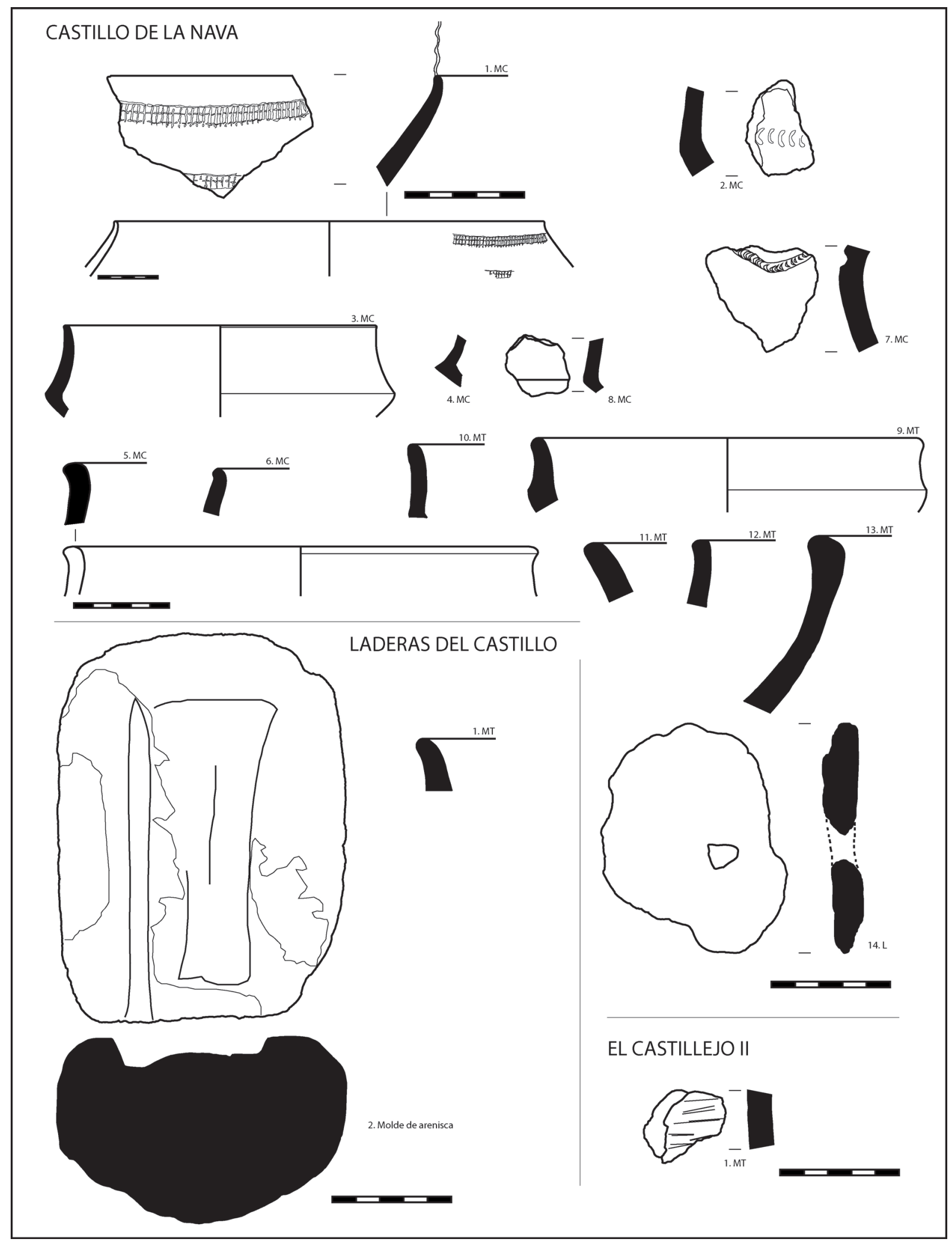

Figura 10. Materiales de superficie del Castillo de la Nava, Laderas del Castillo y El Castillejo II.

ISSN: $1133-4525$ ISSN-e: 2255-3924 


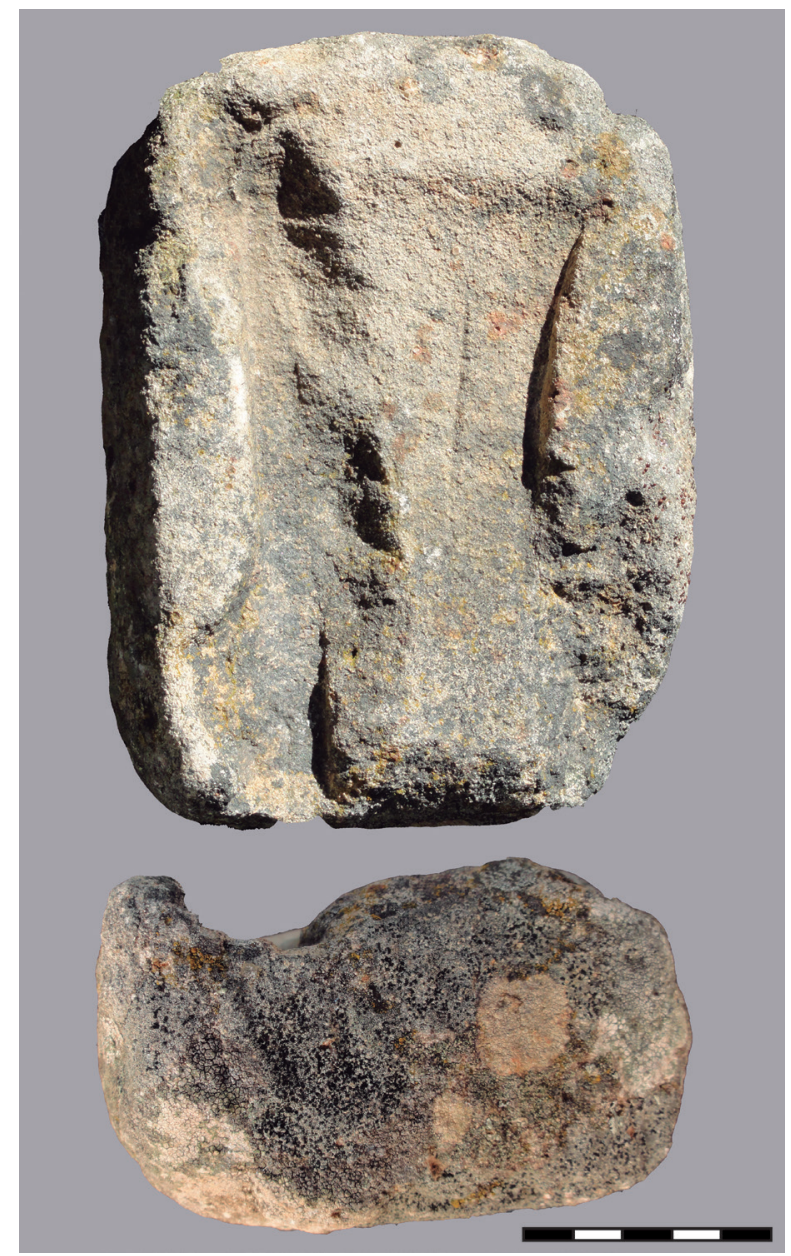

Figura 11. Molde de arenisca de las Laderas del Castillo de la Nava.

a cerca de 3 ha. Estos incluyen, como en el caso anterior, fragmentos cuidados de vasijas decoradas con impresiones (bandas de motivos reticulados, semicírculos, etc.), así como otros lisos, tanto con superficies bruñidas diversamente conservadas, con carenas bajasmedias muy marcadas, como toscas (fig. 10). Ambas remiten, de nuevo, a los horizontes del Bronce Pleno avanzado y Bronce Tardío o Bronce Final I de la secuencia extremeña y encuentran una vez más en el Cerro del Castillo de Alange piezas parecidas (Pavón 1998b: 46, 62 y 82-83), si bien -en el caso de las decoradas- no son exactamente iguales. En tierras cordobesas y sevillanas, por su parte, formas y decoraciones también asimilables pueden reconocerse en los yacimientos ya mencionados. De las Laderas del Castillo de la Nava procede también una pieza destacable: un fragmento de molde de arenisca para elaborar hachas $y$ tal vez cinceles, que fue encontrado hace unos meses por D. A. López Rodríguez (fig. 11). A pesar de conservarse de forma deficiente posee gran interés, y no solo por pertenecer a un molde destinado a la fabricación de diferentes modelos de piezas -que tan conocidos resultan en el Bronce Final atlántico, peninsular y extremeño (Coffyn 1985: 257; Rodríguez et al. 2013: 104)-, sino también por permitir una aproximación tipo-cronológica al producto resultante. Así, aunque en principio podría pensarse en su vinculación a la elaboración de un hacha plana, el hecho de mostrar la huella de una suerte de nervadura central, ausente entre las planas del suroeste peninsular (Schubart 1975: tablas 44-52), pero por el contrario relativamente frecuente en las palstaves o hachas de talón atlánticas (Fernández Manzano 1986: 39 y 62), permite sugerir, pese a conservarse incompleto, esa morfología y su adscripción hacia finales de la Edad del Bronce. También en esta ocasión, el asentamiento dispone de una visibilidad envidiable, tanto hacia el corredor natural que conecta Los Pedroches con el Guadiana Medio como hacia el noroeste; pero más concretamente puede relacionarse con el control estratégico de la salida del puerto de La Nava

Idéntica adscripción crono-cultural podría proponerse, en base al material de superficie, para el asentamiento de La Morisca (fig. 8, C). Estamos, en este caso, ante una ocupación a media ladera (en torno a unos $700 \mathrm{~m}$ s.n.m.), de dimensiones más limitadas, en torno a 0,7 ha. No es descartable, en cualquier caso, que fuera algo mayor, en tanto nos consta la recuperación de material más al oeste. Como en las ocupaciones anteriores, procedentes de aquí se conocen fuentes troncocónicas de carena alta, borde vertical y labio indicado, asimilables a las conocidas manifestaciones de Cogotas I, así como fragmentos decorados con impresiones e incisiones que remiten a casos similares de los horizontes proto- y cogoteño en la Baja Extremadura y Andalucía Centro-Occidental ya aludidos (fig. 12). No es descartable, en todo caso, que el asentamiento perviviera algo más, dada la recogida de posibles fragmentos de cerámica gris en sus superficies (fig. 9). También en esta ocasión estamos ante un poblado con gran dominio visual que, situado frente al Montón, se proyecta sobre todo al sudeste, al gran valle de conexión con Córdoba.

El enclave de Piedra la Huerta, por su parte, es otro típico asentamiento en ladera y alto (en torno a $800 \mathrm{~m}$ s.n.m.) (fig. 8, D). Sus dimensiones se acercan a 0,5 ha $\mathrm{y}$ en su superficie se han recogido fragmentos cerámicos amorfos y algunos reconocibles que remiten a cuencos hemisféricos, ollas globulares y cuencos carenados cuidados. Estos últimos se identifican, por ejemplo, con 


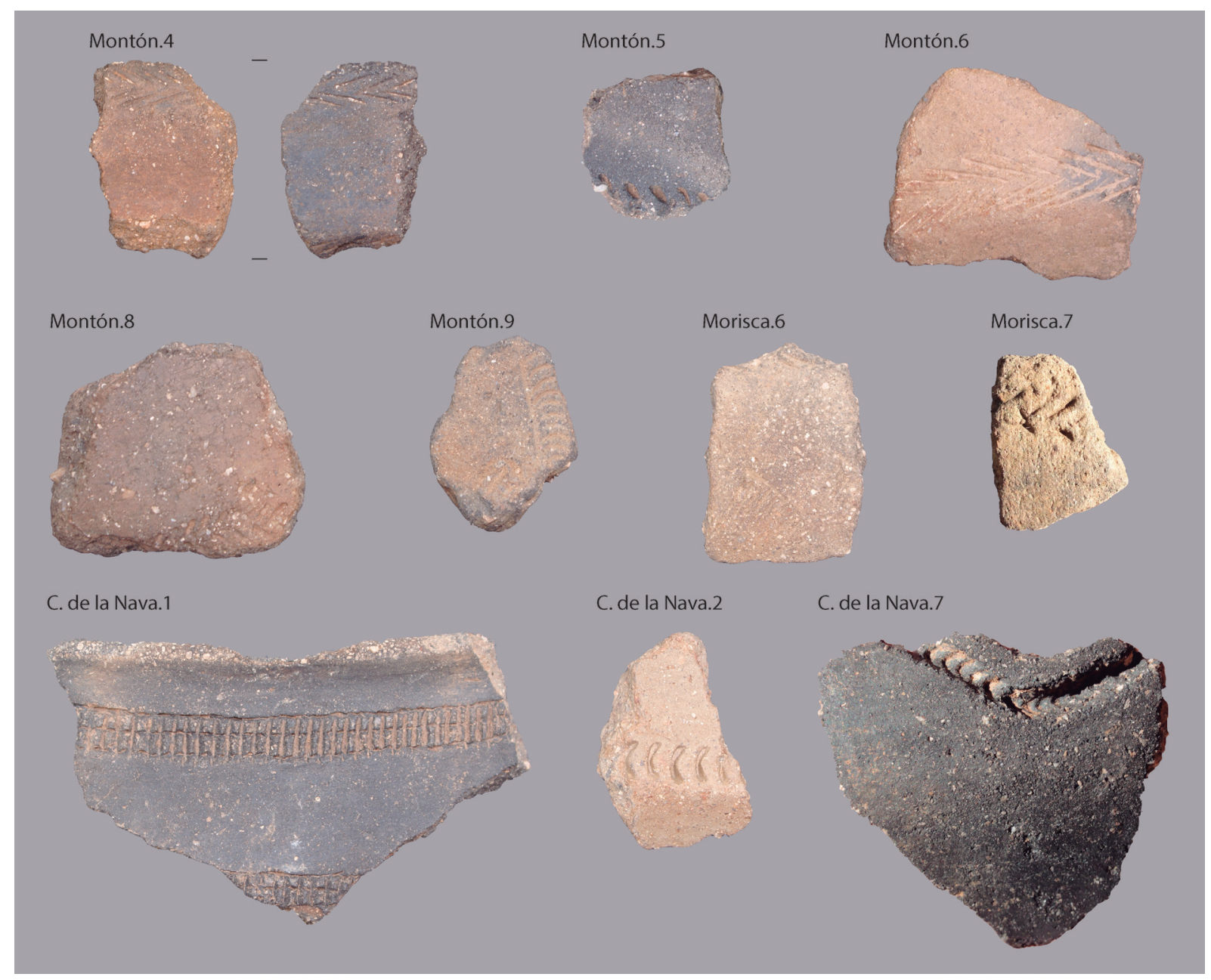

Figura 12. Cerámicas decoradas de El Montón, La Morisca y Castillo de la Nava (diversas escalas).

la forma 3.a.1 del Cerro del Castillo de Alange (Pavón 1998b: 40) y pueden por tanto sugerir una ocupación del sitio en el Bronce Pleno (fig. 9). Dispone, como los anteriores, de una visibilidad extensísima y, situado frente al Castillo de la Nava, ejerce con este el control directo del mejor acceso al puerto de la Nava desde el sur. Cabe añadir que en todos estos enclaves y en sus inmediaciones se han documentados múltiples fragmentos de molinos barquiformes de granito, algunos incluso prácticamente completos, que refrendan una ocupación intensa y quién sabe si ocupaciones menores subsidiarias.

Algo menos definidas que las de los cuatro poblados mencionados son, sin embargo, las cerámicas recuperadas en otros enclaves, que podrían adscribirse en general a la prehistoria reciente. Así, calcolíticas parecen en principio las ocupaciones de Sierra de los Pinos (Castuera) y Valdejazmín (Benquerencia); y en el paraje de la Buitrera, vinculada al control directo del puerto Mejará, conocemos -al margen del recinto torre de altura de época romano-republicana (Ortiz 1995)varios posibles asentamientos, como el de Buitrera II, cuya alfarería a mano no permite por el momento mucha más precisión. No sería descartable, en particular en este último caso, una ocupación del Bronce, puesto que conocemos testimonios que mencionan la recogida en sus laderas de cazuelas carenadas, pero que en nuestras búsquedas no hemos podido documentar. En las inmediaciones a menor cota de todas estas ocupaciones en alto, por el momento, no se conocen poblados del Bronce. Únicamente hemos podido recoger algún fragmento a mano tosco escobillado al sur del asentamiento del Castillejo, en las afueras de Helechal, que hemos denominado El Castillejo II (situado a $590 \mathrm{~m}$ s.n.m.) y que acaso no sea sino el rastro de una muy 


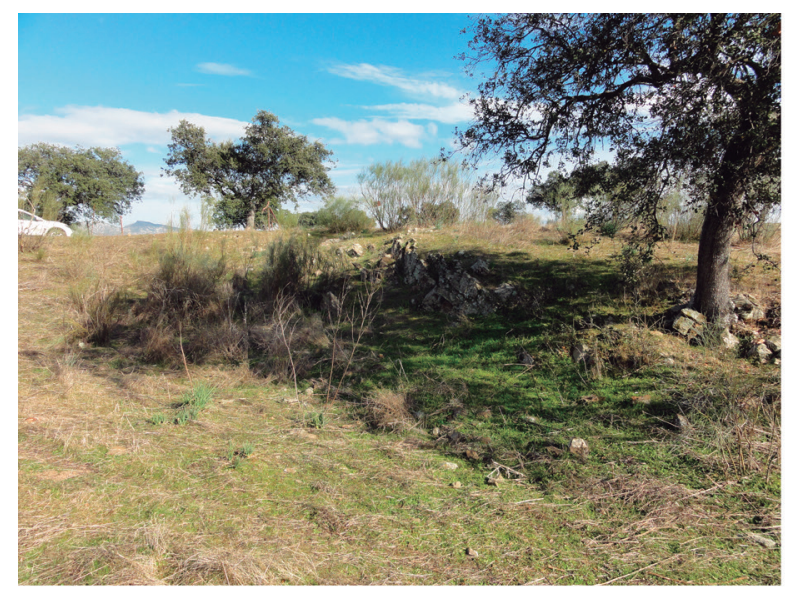

A

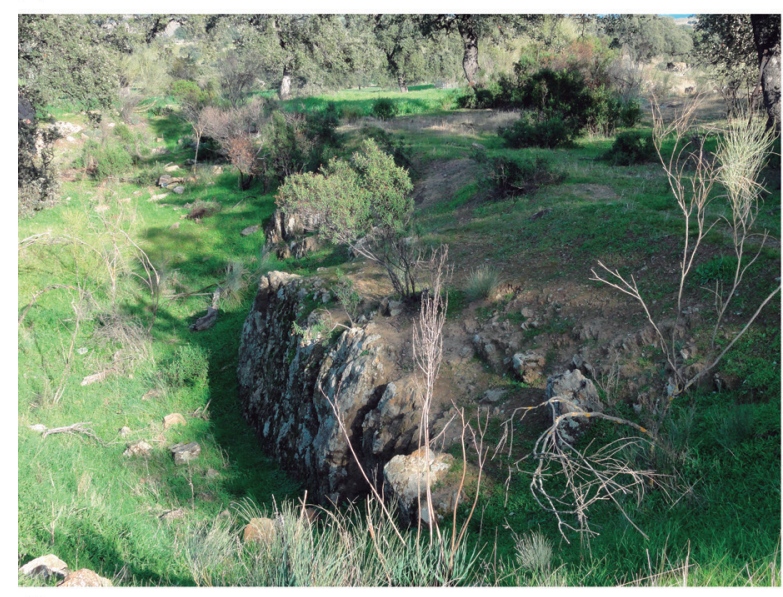

C

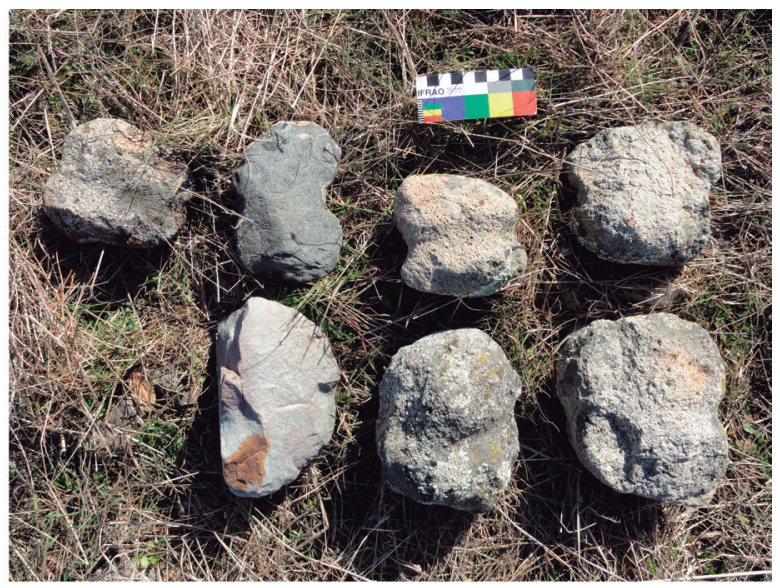

B

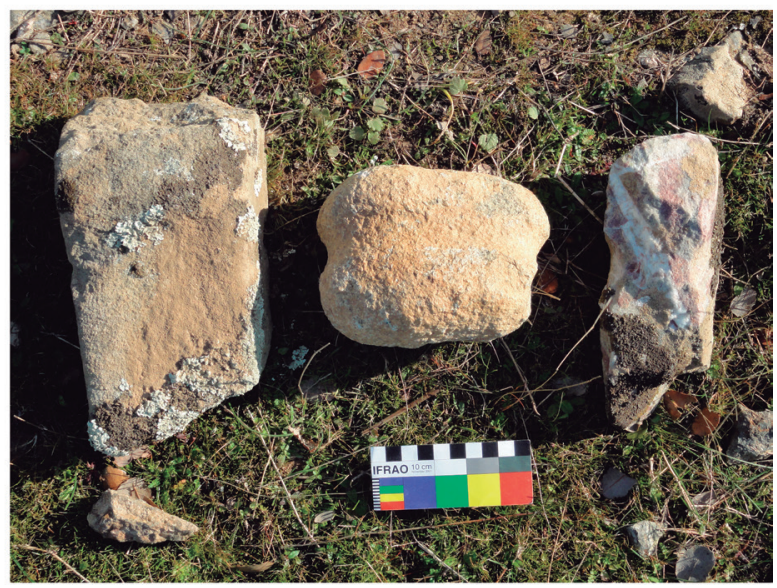

D

Figura 13. A-B) Vista y mazas de El Enjambradero; C-D) vista y mazas de Fuente la Zarza.

pequeña y fugaz ocupación del Bronce Final, puesto que su extensión no supera los $30 \mathrm{~m}^{2}$ (fig. 10). Sabida es la dificultad para detectar en el llano asentamientos de tan pequeñas dimensiones; pero su identificación a partir de este registro invita, al menos teóricamente, a contemplar su existencia junto a las cotas más bajas y en los suelos posiblemente más aptos. Por su parte, el mencionado yacimiento del Castillejo - del que proceden algunos conocidos materiales protohistóricos (entre los que destacan los platos "tipo margarita") dados a conocer hace años por A. Domínguez (1989)-, se encuentra hoy tan alterado que resulta irreconocible en sus características, si bien parece claro que debe adscribirse ya a época postorientalizante, dada la morfología de los materiales aún visibles en superficie, que incluyen vasos a mano toscos, a torno toscos y oxidantes, y platos grises que tienen sus mejores paralelos en $\mathrm{La}$ Mata de Campanario (Rodríguez Díaz 2004), además de algún martillo de minero antiguo, aunque de cronología incierta.

En relación con esta misma problemática, entre los varios casos que se conocen hemos podido reconocer dos explotaciones mineras al sur de la Sierra de Tiros que no están registradas en el mapa de mineralizaciones. Como muchas de las sí catalogadas, se sitúan sobre los terrenos llanos del complejo esquisto-grauváquico. Se trata de las minas de El Enjambradero y Fuente La Zarza que, en función del abundante número de martillos y mazas visibles en superficie, y las huellas observadas en el paisaje, denotan una dedicación concienzuda a las tareas extractivas (fig. 13, A-D). Aparte de dichas herramientas, que elaboradas en cuarcita, cuarzo, roca sedimentaria y granito muestran una cierta diversidad tipológica -incluida alguna pieza con mango, de tipología similar a las documentadas en San Cristóbal de Logrosán (Rodríguez et al. 
2001: 155)-, el reconocimiento superficial no nos ha permitido sin embargo advertir restos cerámicos o de otro tipo que permitan precisar su adscripción. La Morisca es el poblado, de los conocidos, más cercano a estas minas, distante a unos $5 \mathrm{~km}$, pero no cabe descartar su vinculación a otros aún por explorar y eventualmente más próximos.

\subsection{Los hallazgos aislados}

Finalmente, en el apartado de hallazgos aislados vamos a referir muy brevemente otras piezas coetáneas a la que aquí hemos dado a conocer y que, al margen de la ya mencionada espada de lengua de carpa de la Colección Martínez de la Mata -según se dice, procedente de las inmediaciones de Almorchón (el paso natural desde el sur que se abre entre las sierras de Tiros y La Rinconada-La Osa)-, se han asociado con diverso grado de verosimilitud al entorno inmediato de la Sierra de Tiros. La primera de ellas sería un fragmento de torques macizo de oro del Bronce Final, vinculado a la orfebrería "Sagrajas-Berzocana", al parecer procedente de Castuera. Publicada en el marco de una exposición sobre torques realizada por el MAN (Rodero y Barril 2002: 204-205), se trata de una pieza realizada mediante vaciado en molde, martillado y pulido con decoración a cincel, que mide $3,70 \mathrm{~cm}$ de longitud por 1,70 de grosor y pesa 125,61 gr. Además de este, según un estudio reciente de J. J. Enríquez (2017: 98) hay otros dos fragmentos más de la misma pieza, que fue rota intencionadamente en tres trozos, uno atesorado en una colección privada italiana y el tercero, como este, en paradero desconocido.

Pero, dejando a un lado el hallazgo de una dudosa estela con tocado en Helechal (Díaz-Guardamino 2010: 228 y 753), los otros hallazgos aislados de mayor interés para la contextualización de la nueva estela de Cabeza del Buey V/El Palacio son las también denominadas de Benquerencia de la Serena (Enríquez 1982a: 65-66) y Cabeza del Buey III/El Corchito (Almagro Gorbea 1977: lám. XIX-3). Ambas comparten con la dada a conocer aquí -como más atrás dijimossu inclusión en el grupo de las estelas de guerrero con espada al cinto (fig. 14). Más allá de ello, son interesantes los datos sobre sus ubicaciones. Así, la de Benquerencia, que según se ha escrito procede de una finca indeterminada perteneciente a dicho término, podemos situarla gracias a informantes de la zona en un paraje cercano a los arroyos de La Venta y Lavandero (en las fuentes del río Guadalefra, junto a la Dehesa de
Benquerencia), a una altitud de en torno a los $500 \mathrm{~m}$ s.n.m. El dato viene a confirmar la suposición de que apareció en el valle (Celestino 2001: 385) y a corregir la cartografía que por el contrario la ubicaba (aunque con reservas) al norte de la Sierra de Benquerencia (Galán 1993: 40). El hallazgo de la de Cabeza del Buey III/El Corchito se vincula a la finca homónima, sita unos $9 \mathrm{~km}$ al oeste de esa población. Ambos ejemplares tienen aire de familia con la nueva de El Palacio -todas con guerrero sin tocado y espada al cinto, reiteramos-; pero más allá de ello no hay más rasgos iconográficos que las vinculen especialmente. Por su parte, el resto de las estelas aparecidas en dicho término se recuperaron a una distancia de entre $10-15 \mathrm{~km}$ al norte del núcleo urbano, de manera que se alejan del espacio ahora en estudio.

\section{UNA VALORACIÓN GENERAL DESDE LA ARQUEOLOGÍA DEL PAISAJE-TERRITORIO}

Como es bien conocido, las estelas de guerreros han sido uno de los elementos de la prehistoria reciente / protohistoria más valorados desde una perspectiva espacial, sobre todo a partir de comienzos de los años 1990 , en que se dio un salto desde las aproximaciones al fenómeno en su escala "geográfica" (o macro) a su estudio en los niveles meso y microespaciales (Barceló 1989; Celestino 1990 y 2001; Ruiz-Gálvez y Galán 1991; Galán 1993). La información aportada en las páginas precedentes permite incidir en esta tendencia, aunque desde el planteamiento, hecho explícito en este punto, de que no se pretende aquí una valoración global del significado, función e interpretación de (todas) las estelas, sino tan solo una aproximación a su papel en el contexto particular de la Sierra de Tiros y a un nivel mesoespacial. Así, propondremos seguidamente su integración en un discurso que contemple el resto de evidencias del poblamiento pre- y protohistórico, desarrollando -acaso en esta ocasión con un mayor grado de precisión- una línea ya esbozada en trabajos previos (Pavón 1998a: 78-87; Pavón y Duque 2010: 120-124) y reivindicada de alguna forma en las nuevas visiones del fenómeno (Díaz-Guardamino 2010: 327).

Desde esta perspectiva, una vez admitido el referente visual que es la Sierra de Tiros, perceptible a unos 50 kilómetros desde el valle Serena-Pedroches, el análisis espacial de las estelas aparecidas en su entorno pasa en primer lugar por definir el poblamiento sincrónico. Aunque, como hemos visto, disponemos solo de 
material de superficie para su valoración, es muy probable que sitios como El Montón, el Castillo de La Nava, La Morisca y Piedra la Huerta constituyan los mejores candidatos para ello. En todas las ocasiones se constatan ocupaciones en alto o dispuestas en las laderas meridionales más soleadas que puntualmente, como hemos podido apreciar en el extremo oriental de El Montón, exhiben elementos ideográficos pintados en plena sintonía con los de las estelas. Lejos de ser un detalle menor, esta circunstancia permite vincular culturalmente ambos conjuntos de evidencias, de manera que -con independencia de que tales poblados pudieran tener su origen en el Bronce Pleno o incluso antes- invita a contemplarlos también en un mismo plano cronológico, a grandes rasgos avalado por los fragmentos cerámicos recuperados en sus superficies y, en segundo plano, por otros hallazgos aislados cercanos, como la espada de lengua de carpa procedente al parecer del entorno de Almorchón.

En torno a dichos poblados podemos definir sus teóricos territorios de explotación o captación de recursos, marcados a 3 y $5 \mathrm{~km}$, y como puede apreciarse en buena parte solapados e integrados todos ellos en una misma sub-cuenca hidrográfica, la del Arroyo Benquerencia, afluente del Zújar por el oeste (fig. 15). Tal maniobra aleja sin embargo a la estela de Benquerencia de la dinámica histórica, socioeconómica y política vinculada a dichos poblados, pues queda fuera de su proceso de territorialización (aunque no sería descartable su vinculación a otro paralelo desarrollado en relación con el área de la Sierra del Oro y Monterrubio de la Serena). Más allá de lo expresado en el epígrafe precedente, resulta interesante atender al grado de visibilidad conjunta que se dispone desde los cuatro asentamientos, en especial dentro de su territorio teórico de captación $(5 \mathrm{~km})$; así, prácticamente todo él está visualmente controlado, salvo una buena porción del cuadrante nororiental que es, curiosamente, donde aparecieron las estelas de Cabeza del Buey V/El Palacio y Cabeza del Buey III/El Corchito. En nuestra opinión, tales registros ideográficos podrían ejercer aquí una función complementaria a la del propio poblamiento, marcando en áreas invisibles a este los procesos de apropiación e identidad que en las visibles ejerce la simple localización y percepción de los asentamientos. Acaso no esté de más apuntar que dichas estelas, además, coinciden con escenarios transicionales entre distintos sustratos edafo-geológicos (tierra parda meridional y xeroranker de erosión sobre el complejo esquisto grauváquico / suelos coluviales sobre ladera y crestones cuarcíticos), entre distintas sub-cuencas hidrográficas -ubicándose en las cotas de sus cabeceras (particularmente en las fuentes del Arroyo de Almorchón, afluente del Zújar por el sur)- y al paso de los propios accesos a los puertos de Almorchón y La Nava. Ello no significa que en este caso las entendamos, como a menudo se ha planteado, como meros demarcadores de rutas ganaderas o comerciales en el marco de un patrón de asentamiento inestable, aún no sedentario e itinerante (Galán 1993: 38 y 53-60), sino como elementos plenamente integrados en una dinámica poblacional visible, con vocación de permanencia y plenamente arraigada en el tiempo.

Buena prueba de ello nos parece el propio análisis del poblamiento en relación a los recursos potenciales, que proponemos aquí esencialmente a partir de la valoración de los suelos en su aptitud agrícola, y del interés minero-metalúrgico del subsuelo (fig. 16, A-D). En relación con los suelos, solo mencionamos que en el entorno estudiado se identifican, según la cartografía del 1:250.000 del mapa de suelos de la provincia de Badajoz (MAPA 1968), cinco variedades con diferentes capacidades (tierra parda meridional y xeroranker de erosión sobre el complejo esquisto grauváquico, o sobre granito; suelos coluviales sobre ladera y crestones cuarcíticos; suelo pardo mediteráneo; y rellenos sobre fondo de valle terciarios-cuaternarios), que, teniendo en cuenta su lectura combinada con los niveles de insolación y la inclinación de pendientes de los terrenos donde se ubican, son susceptibles de articularse en cuatro tipos. El tipo A estaría representado por los suelos más aptos para la agricultura, con apreciables extensiones al sur de la Sierra de Tiros y a distancias asequibles de los poblados conocidos, que representan casi el $37 \%$ de la superficie distante a menos de 3 $\mathrm{km}$, es decir del territorio de explotación propiamente dicho (un territorio explotado que en total supondría unas 5.721 ha). El tipo B lo integrarían los suelos aptos para el desarrollo agrícola, que tienden a situarse en el entorno más inmediato a la sierra y representan algo más del $20 \%$ de dicho territorio de explotación. El C, por su parte, agrupa a los terrenos solo apto para manejo antrópico relacionado con pastos, tanto al norte como al sur del territorio de explotación, que vienen a suponer casi el 20\% de la superficie. Finalmente, el tipo D, que es nulo en términos agropecuarios pero complementario para el desarrollo de una actividad silvo-pastoril (recolección de frutos, caza, aprovisionamiento de leña, ramoneo...), representaría algo más del $23 \%$ de la superficie distante a menos de $3 \mathrm{~km}$. (fig. 16, E). Particular interés merece, en este contexto, el paraje de Navacerrada, una suerte de valle interior con tierras capaces y bien soleadas, con disponibilidad 


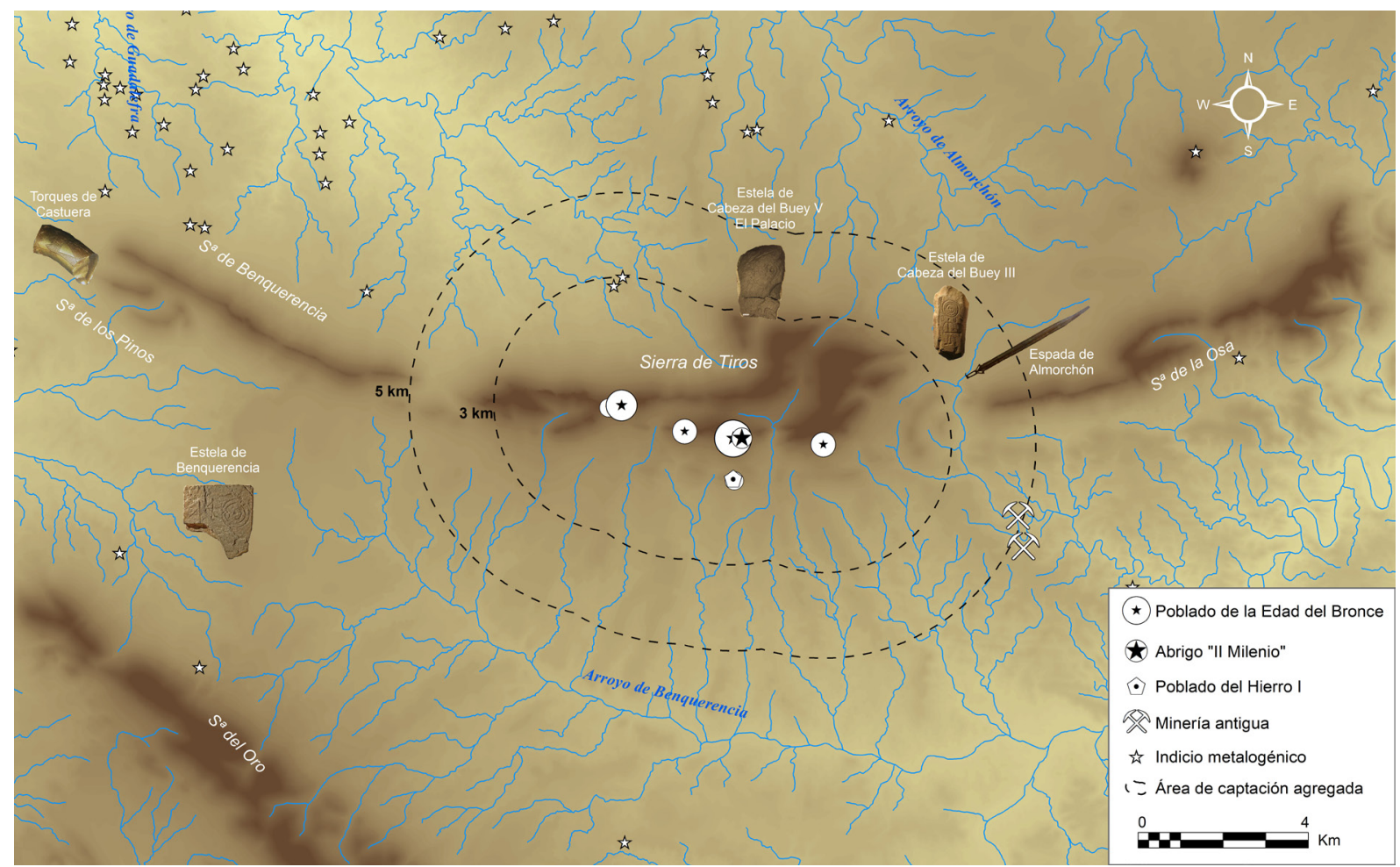

Figura 14. Poblamiento y hallazgos aislados de la Edad del Bronce en el entorno de la Sierra de Tiros.

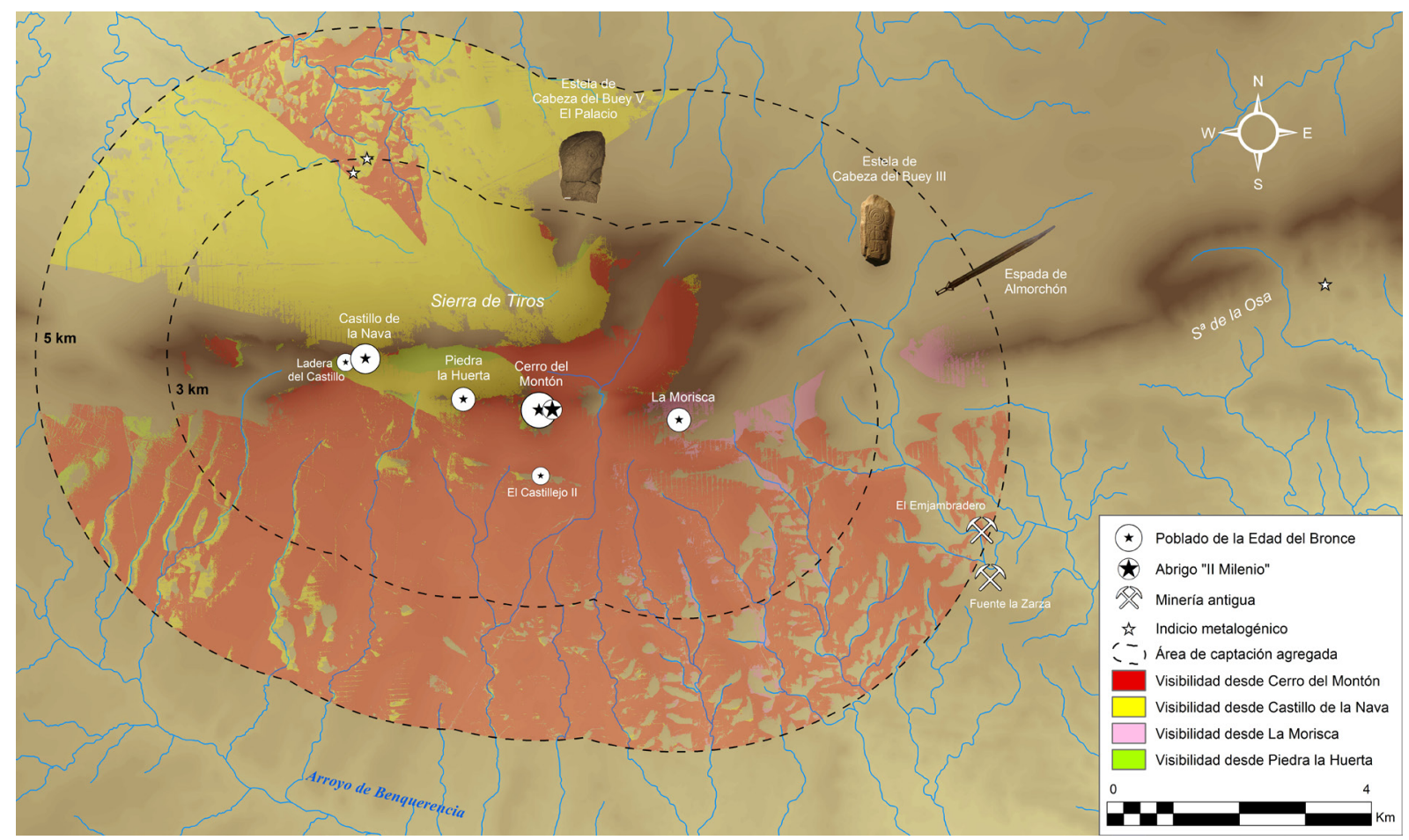

Figura 15. Visibilidades acumuladas en las áreas de captación de los poblados de la Edad del Bronce de la Sierra de Tiros.

ISSN: $1133-4525$ ISSN-e: $2255-3924$ 


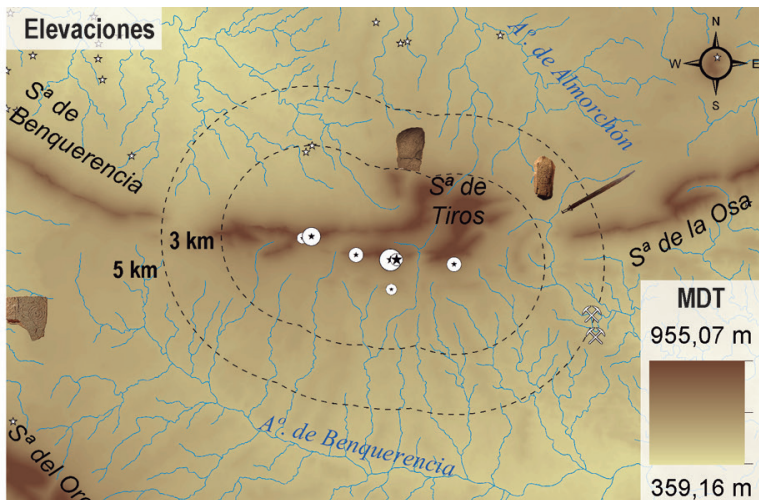

A

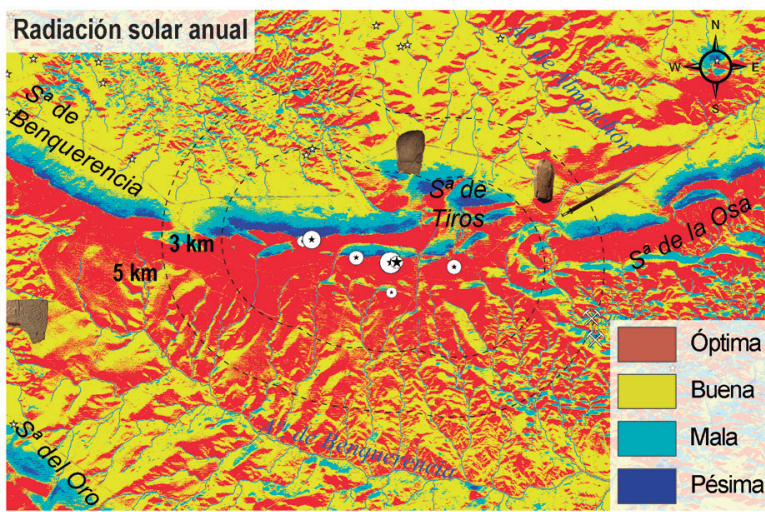

C

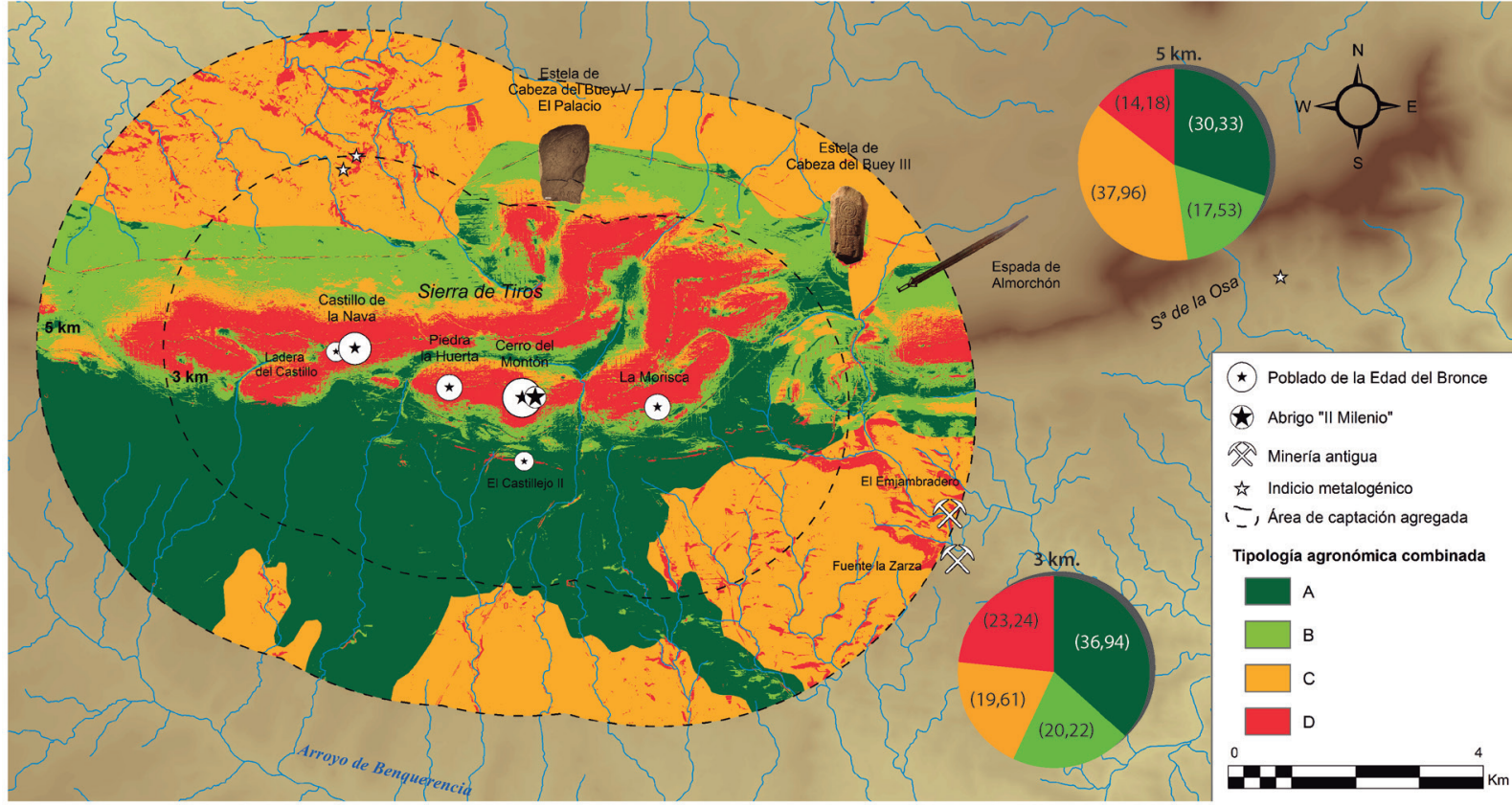

$\mathrm{E}$

Figura 16. A) Modelo Digital del Terreno; B) Mapa de suelos; C) Mapa de radiación solar anual; D) Mapa de aptitudes de las pendientes para desarrollo agropecuario; E) Resultado espacial y porcentual de las aptitudes agrarias de los suelos en las áreas de captación de los poblados de la Sierra de Tiros. 
de agua -no en vano, allí confluyen las escorrentías de la sierra y nace el arroyo de Navacerrada, que confluye en el mencionado Benquerencia- que parece capitalizar la atención de todo el poblamiento (que controla los accesos al mismo, a través de La Nava y Las Calderas) y debió constituir una suerte de reservorio agrícola y, tal vez, de otros recursos.

Se trata de un patrón de asentamiento, por tanto, que compatibiliza las necesidades de visualización y control territorial de los pasos con el aprovechamiento directo de los suelos más fértiles, llanos y soleados, donde no descartamos un poblamiento menor subsidiario vinculado a las tareas agrícolas, sugerido en este caso por la ocupación del Castillejo II. No son abundantes los estudios paleoambientales y económicos sobre el Bronce Final extremeño, pero los existentes (Duque 2004; Duque y Pérez 2007; Pavón y Duque 2014) no refrendan en absoluto el discurso insistentemente expuesto por diversos autores sobre la ganadería - ¡incluso en régimen trashumante!como vector de explotación prácticamente exclusivo por causa de un estiaje extremo que se asume y proyecta incluso en las visiones de síntesis más recientes (Celestino y Rodríguez 2017: 27). Por el contrario, desde comienzos del Bronce Final se asiste en algunos puntos del Guadiana Medio a lo que parece una intensificación de la actividad agrícola cerealista, con antecedentes en el Bronce Pleno -como sucede particularmente en Alange- (Rodríguez 2009: 61; Pavón y Duque 2014: 56); en tanto la actividad minera en torno al estaño empieza a constarse arqueológicamente con pruebas irrefutables (Rodríguez et al. 2013), con lo que cabe pensar en una economía globalmente más diversa que la tradicionalmente contemplada. En este sentido, y en relación con esta otra manifestación de una economía complementaria, en el área de captación teórica de estos poblados también conocemos la existencia de algunas mineralizaciones de cobre, cuya explotación en época antigua, como hemos visto, es más que viable. De manera que, disponiendo de pastos abundantes y tierras muy aptas para la agricultura, desde estos poblados se tendría también la posibilidad de extraer mediante una minería de superficie recursos metálicos básicos y completar así las demandas esenciales para un poblamiento estable. En suma, las evidencias simbólicas y poblacionales mencionadas, sus patrones de asentamiento y su relación con recursos económicos diversos nos llevan a pensar en las estelas como las plasmaciones iconográficas más representativas de un sistema de apropiación directa del territorio por unas jefaturas complejas asentadas hacia finales de la Edad del Bronce en la Sierra de Tiros.

\section{Agradecimientos}

Los autores desean agradecer a D. Jesús Fernández López, a D. Sinué Medina Fernández y a D. Antonio López-Rodríguez, grandes conocedores de las sierras de Benquerencia y Tiros, su ayuda en los trabajos de campo conducentes a la elaboración de este estudio.

Este trabajo se enmarca en una de las líneas investigadoras del G.I. PRETAGU que actualmente desarrolla en el proyecto "Arqueología y recuperación de un paisaje minero. La explotación tartésica del estaño en San Cristóbal de Logrosán (Cáceres)" (HAR201452922-P).

\section{BIBLIOGRAFÍA}

Abarquero Moras, J. (2005): Cogotas I. La difusión de un tipo cerámico durante la Edad del Bronce. Arqueología en Castilla y León 4. Valladolid, Junta de Castilla y León.

Almagro Basch, M. (1940): "El hallazgo de la Ría de Huelva y el final de la Edad del Bronce en el Occidente de Europa". Ampurias 2: 85-143.

Almagro Basch, M. (1966): Las estelas decoradas del suroeste peninsular. Bibliotheca Praehistorica Hispana VIII. Madrid, Consejo Superior de Investigaciones Científicas.

Almagro-Gorbea, M. (1977): El Bronce Final y el Período Orientalizante en Extremadura. Bibliotheca Praehistorica Hispana XIV. Madrid, Consejo Superior de Investigaciones Científicas.

Anlen, L. y Padiou, R. (1989): Les miroirs de bronze anciens. Symbolisme \& tradition. París, Guy Trédaniel Éditeur.

Barceló, J. A. (1989): "Las estelas decoradas del sudoeste de la Península Ibérica", en M. E. Aubet (coord.), Tartessos. Arqueología protohistórica del Bajo Guadalquivir: 189-208. Sabadell, Ausa.

Bendala Galán, M. (1977): "Notas sobre las estelas decoradas del suroeste y los orígenes de Tartessos". Habis 8: 177-205.

Bendala, M.; Hurtado, V. y Amores, F. (1980): “Tres nuevas estelas de guerrero en la provincia de Córdoba". Habis 10-11: 381-390.

Bonsor, L. y Thouvenot, R. (1928): Nécropole Ibérique de Setefilla, Lora del Río, Sevilla. Fouilles de 
1926-1927. Burdeos, Bibliothèque de L'École des Hautes Études Hispaniques.

Brandherm, D. (2007): Las Espadas del Bronce Final en la Península Ibérica y Baleares. Prähistorische Bronzefunde, Abteilung IV, 16. Band. Stuttgart, Franz Steiner Verlag.

Brandherm, D. y Moskal-Del Hoyo, M. (2014): "Both sides now: the carp's tongue complex revisited". The Antiquaries Journal 94: 1-47.

Bueno, P. y Piñón, F. (1985): “La estela de Monte Blanco, Olivenza (Badajoz)", en Estudios de Arqueología Extremeña (Homenaje a Cánovas Pessini): 37-43. Badajoz, Diputación Provincial de Badajoz.

Celestino Pérez, S. (1985): "Los carros y la estelas decoradas del suroeste", en Estudios de Arqueología Extremeña (Homenaje a Cánovas Pessini): 45-55. Badajoz, Diputación Provincial de Badajoz.

Celestino Pérez, S. (1990): "Las estelas decoradas del S.W. peninsular”, en A. Velázquez, J. L. de la Barrera y J. J. Enríquez (eds.), La cultura tartésica y Extremadura. Cuadernos Emeritenses 2: 45-62. Mérida, Museo Nacional de Arte Romano.

Celestino Pérez, S. (2001): Estelas de guerrero y estelas diademadas. La precolonización y formación del mundo tartésico. Barcelona, Bellaterra Arqueología.

Celestino, S. y Rodríguez, E. (2017): “Tarteso: una cultura ente el Atlántico y el Mediterráneo", en S. Celestino (Coord.), Protohistoria en la Península Ibérica: 13-147. Madrid, Istmo.

Coffyn, A. (1985): Le Bronze Final Atlantique dans la Péninsule Ibérique. París, De Boccard.

Collado Giraldo, H. (2006): Arte rupestre del valle del Guadiana. El conjunto de grabados del Molino Manzánez (Alconchel-Cheles, Badajoz). Memorias de Odiana 4. Beja, EDIA.

Collado Giraldo, H. (2015): "New representations of 'chariots' in the rock art of Extremadura and some considerations of the archaeological context". Arts 4: 49-60

Collado Giraldo, H. (2016): "A mark along the way: schematic rock art and communication routes". Arts 5-6: 1-11.

Collado, H. y García, J. J. (2010): “10.000 años de arte rupestre. El ciclo preesquemático de la Península Ibérica y su reflejo en Extremadura (España)", en Actas del Congreso IFRAO 2009. Parque Nacional de la Sierra de Capivara (Piaui, Brasil), Fumdhamentos IX, vol. IV, sesión 23: 1167-1192.

Collado, H. y García, J. J. (2013): "Reflexiones sobre la fase inicial del arte rupestre esquemático en Extremadura a raíz de las recientes investigaciones", en
J. Martínez y M. Hernández (eds.), Arte Rupestre Esquemático en la Península Ibérica. Comarca de los Vélez 5-8 Mayo 2010: 287-300. Vélez-Blanco, Ayuntamiento de Vélez-Blanco.

Collado, H.; Rosina; P. L.; García, J. J.; Gomes, H.; Nobre, L.; Domínguez, I. M.; Duque, D.; Fernández, J. M.; Blasco E.; Torrado, J. M.; Rodríguez, L.; Rivera, E.; Nacarino, M.; Capilla, J. E. y Pérez, S. (2014): "El arte rupestre esquemático del Arroyo Barbaón (Parque Nacional de Monfragüe, Cáceres): Contextualización arqueológica y caracterización de pigmentos". Zephyrus LXXIV: 15-39.

Díaz-Guardamino Uribe, M. (2010): Las estelas decoradas en la Prehistoria de la Península Ibérica. Tesis Doctoral, Universidad Complutense, Madrid. Inédita.

Domínguez de la Concha, A. (1989): Un lote de cerámicas procedentes de Benquerencia de la Serena (Badajoz). Publicaciones 1. Badajoz, Museo de Badajoz.

Domínguez, A. y Aldecoa, M. A. (2007): Arte rupestre de la ZEPA de La Serena: Puebla de Alcocer, Esparragosa de Lares y Campanario, en H. Collado y J. J. García (coords.), Corpus de Arte Rupestre en Extremadura Vol. II. Mérida, Junta de Extremadura.

Domínguez, C.; González, J. M. y De Hoz, J. (2005): Catálogo de estelas decoradas del Museo Arqueológico Provincial de Badajoz. Siglos VIII-V .C. Mérida, Junta de Extremadura.

Duque Espino, D. M. (2004): La gestión del paisaje vegetal en la Prehistoria reciente y Protohistoria en la Cuenca Media del Guadiana a partir de la Antracología. Tesis Doctoral, Universidad de Extremadura, Cáceres. Inédita.

Duque, D. M. y Pérez, G. (2007): “Análisis antracológico y carpológico de los hoyos del Carrascalejo: medio vegetal y agricultura en la Edad del Bronce en la Cuenca Media del Guadiana", en J. J. Enríquez y B. Drake (eds.), El campo de hoyos de la Edad del Bronce del Carrascalejo (Badajoz). Memorias de Arqueología Extremeña 7: 145-157. Mérida, Junta de Extremadura.

Enríquez Navascués, J. J. (1982a): “Dos nuevas estelas de guerreros en el Museo Arqueológico Provincial de Badajoz". Museos 1: 65-68.

Enríquez Navascués, J. J. (1982b): “Una nueva estela de guerrero y tres asadores de bronce procedentes de los alrededores de Orellana la Vieja (Badajoz)". Museos 2: 9-13.

Enríquez Navascués, J. J. (2017): “Tesoros que se fueron. Piezas áureas del Calcolítico y Edad del 
Bronce que emigraron de Extremadura", en A. Rodríguez, I. Pavón y D. M. Duque (eds.), Historias de Tesoros, Tesoros con Historia: 87-123. Cáceres, G.I.PRETAGU y Universidad de Extremadura.

Enríquez, J. J. y Celestino, S. (1984): "Nuevas estelas decoradas en la cuenca del Guadiana". Trabajos de Prehistoria 41: 237-251.

Enríquez, J. J. y Drake, B. (2007): El campo de hoyos de la Edad del Bronce del Carrascalejo (Badajoz), Memorias de Arqueología Extremeña 7. Mérida, Junta de Extremadura.

Estepa García, J. J. (2000): Las grandes cañadas extremeñas. Relatos de La Mesta. Badajoz, Universitas.

Fernández Manzano, J. (1986): Bronce Final en la Meseta Norte española: el utillaje metálico. Valladolid, Junta de Castilla y León.

Fernández Ochoa, C. y Zarzalejos, M. (1994): “La estela de Chillón (Ciudad Real). Algunas consideraciones acerca de la funcionalidad de las 'estelas de guerrero' del Bronce Final y su reutilización en época romana", en C. de la Casa Martínez (ed.), V Congreso Internacional de Estelas Funerarias: 263271. Soria (1993), Soria, Diputación Provincial.

Fernández Oxea, J. R. (1950): "Lápidas sepulcrales de la Edad del Bronce en Extremadura". Archivo Español de Arqueología 78: 290-301.

Ferrer Albelda, E. (1999): "La estela decorada de Montemayor (Córdoba)". Antiqvitas 10: 65-71.

Galán Domingo, E. (1993): Estelas, paisaje y territorio en el Bronce Final el suroeste de la Península Ibérica. Complutum Extra 3. Madrid, Universidad Complutense.

García Sanjuán, L. (1999): Los orígenes de la estratificación social. Patrones de desigualdad en la Edad del Bronce del Suroeste de la Península Ibérica (Sierra Morena Occidental c. 1700-1100 a.n.e./2100-1300 A.N.E.). BAR International Series 823. Oxford, Archaeopress.

Gomes, M. V. (1989): “Arte rupestre do vale do Tejo, um santuário pré-histórico", en Encuentros sobre el Tajo: el agua y los asentamientos humanos. Cuadernos de San Benito 2: 49-75. Alcántara-Lisboa (1988), Alcántara, Fundación San Benito de Alcántara.

Gomes, M. V. y Monteiro, J. P. (1977): "Las estelas decoradas do Pomar (Beja, Portugal). Estudio comparado". Trabajos de Prehistoria 34: 165-212.

Harrison, R. J. (2004): Symbols and Warriors. Images of the European Bronze Age. Bristol, Western Academic \& Specialist Press Limited.

IES Muñoz Torrero de Cabeza del Buey (Badajoz) (2017): http://iesmunoztorrero.juntaextremadura. net/web/aguaserena/laserena/serenafotoshistoria. htm [06/02/2017].

MAPA (1968): Mapa de suelos de la provincia de Badajoz (1:250.000). Sección de Cartografía de Suelos del Instituto Nacional de Edafología y Agrobiología "J. Ma. Albareda". Madrid, Consejo Superior de Investigaciones Científicas.

Martínez Perelló, Ma I. (1995): "Los abrigos pintados de Helechal: un nuevo conjunto de arte rupestre esquemático en Badajoz". Espacio, Tiempo y Forma, Serie I, Prehistoria y Arqueología 8: 191-233.

Martínez Perelló, M I. (1999): La pintura rupestre esquemática en Extremadura sudoriental. Tesis Doctoral, UNED, Madrid. Inédita.

Mederos Martín, A. (2008): “Carros micénicos del Heládico Final III en las estelas decoradas del Bronce Final II-IIIA del suroeste de la Península Ibérica", en S. Celestino, N. Rafel y X. L. Armada (eds.), Contacto cultural entre el Mediterráneo y el Atlántico (siglos XII-VIII ane). La precolonización a debate: 437-463. Madrid. Consejo Superior de Investigaciones Científicas.

Mederos, A. y Harrison, R. J. (1996): "Patronazgo y clientelas. Honor, guerra y festines en las relaciones sociales de dependencia del Bronce Final Atlántico en la Península Ibérica". Pyrenae 27: 31-52.

Mederos, A. y Jiménez, J. (2016): "Las fíbulas de codo del Bronce Final en Extremadura y las representadas en las estelas del Suroeste de la Península Ibérica. A propósito de una nueva fíbula del Castillo de Guadajira (Lobón, Badajoz)", en Homenaje a la profesora Concepción Blasco Bosqued. Anejos a Cuadernos de Prehistoria y Arqueología de la Universidad Autónoma de Madrid 2: 117-134. Madrid, Universidad Autónoma.

Murillo, J. F.; Morena, J. A. y Ruiz, D. (2005): "Nuevas estelas de guerrero procedentes de las provincias de Córdoba y de Ciudad Real". Romula 4: 7-46.

Needham, S. P.; Northover, P.; Uckelmann, M. y Tabor, R. (2012): "South Cadbury: the last of the bronze shields?". Archäologisches Korrespondenzblatt 424: 473-491.

Oliva, D. y Chasco, R. (1976): “Una estela funeraria con escudo de escotadura en U en la provincia de Sevilla”. Trabajos de Prehistoria 33: 387-389.

Ortiz Romero, P. (1995): "De recintos torres y fortines: usos (y abusos)", en Homenaje a la Dra. Milagro Gil-Mascarell Boscà. Extremadura Arqueológica V: 177-193. Cáceres, Universidad de Extremadura.

Pavón Soldevila, I. (1998a): El tránsito del II al I milenio a. C. en las cuencas medias de los ríos Tajo 
y Guadiana: la Edad del Bronce. Cáceres, Publicaciones de la Universidad de Extremadura.

Pavón Soldevila, I. (1998b): El Cerro del Castillo de Alange (Badajoz). Intervenciones arqueológicas (1993). Memorias de Arqueología Extremeña 1. Mérida, Junta de Extremadura.

Pavón Soldevila, I. (1999): "Los albores de la protohistoria en la 'mesopotamía' extremeña: notas para la discusión de un modelo". Estudos Pré-històricos VII: 179-212.

Pavón, I. y Duque, D. (2010): “La nueva estela de guerrero de Las Bodeguillas (Esparragosa de Lares, Badajoz) y el paisaje cultural del final de la Edad del Bronce en La Serena". Spal 19: 111-128.

Pavón, I. y Duque, D. (2014): "El Cerro del Castillo de Alange (Extremadura, España): un paisaje de la Edad del Bronce", en R. Vilaça y M. Serra (coord.), Idade do Bronze do Sudoeste. Novas perspetivas sobre uma velha problemática: 51-73. Coimbra, Istituto de Arqueologia - Secção de Arqueologia - FLUC.

Pingel, V. (1974): "Bemerkungen zu den ritzverzierten Stelen und zur Beginnen der Eisenzeit im Südwesten der Iberischen Halbinsel”. Hamburger Beiträge zur Archäologie IV: 1-19.

Quesada Sanz, F. (2005): "Carros en el antiguo Mediterráneo: de los orígenes a Roma”, en E. Galán (ed.), Historia del carruaje en España: 16-71. Madrid, FCC-Cinterco.

Rodero, A. y Barril, M. (dirs.) (2002): Torques, belleza y poder. Madrid, Secretaria General del Ministerio de Educación, Cultura y Deporte.

Rodríguez Díaz, A. (coord.) (2004): El edificio protohistórico de La Mata (Campanario, Badajoz) y su estudio territorial. Mérida, Junta de Extremadura.

Rodríguez Díaz, A. (2009): Campesinos y "señores del campo”. Tierra y poder en la protohistoria extremeña. Barcelona, Bellaterra.

Rodríguez, A.; Pavón, I.; Merideth, C. y Juan, J. (2001): El Cerro de San Cristóbal, Logrosán, Extremadura, Spain. The archaeometallurgical excavation of a Late Bronze Age tin-mining and metalworking site. First excavation season 1998. BAR International Series 922. Oxford, Archaeopress.

Rodríguez, A.; Pavón, I.; Duque, D. M.; Ponce de León, M.; Hunt, M. y Merideth, C. (2013): “La explotación tartésica de la casiterita entre los ríos Tajo y Guadina: San Cristóbal de Logrosán (Cáceres)". Trabajos de Prehistoria 70-1: 95-113.

Rodríguez, A.; Pavón, I. y Duque, D. M. (2015): “El estaño de Logrosán en los tiempos de Tartessos: estado actual y perspectivas de futuro", en Actas I Congreso sobre Patrimonio Geológico y Minero de La Serena: 175-187. Castuera, CEDER La Serena.

Ruiz Mata, D. (1995): "Las cerámicas del Bronce Final. Un soporte tipológico para delimitar el tiempo y el espacio tartésico", en Tartessos 25 años después. 1968-1993. Actas del Congreso Conmemorativo del V Symposium Internacional de Prehistoria Peninsular: 265-313. Jerez de la Frontera (1993), Jerez de la Frontera, Ayuntamiento.

Ruiz Rodríguez, A. (1996): "Desarrollo y consolidación de la ideología aristocrática entre los iberos del sur", en Coloquio Internacional Iconografía Ibérica, Iconografía Itálica: propuestas de interpretación y lectura. Serie Varia 3: 61-71. Madrid, Universidad Autónoma de Madrid.

Ruiz-Gálvez, M. y Galán, E. (1991): “Las estelas del suroeste como hitos de vías ganaderas y rutas comerciales". Trabajos de Prehistoria 48: 257-273.

Schubart, H. (1975): Die Kultur der Bronzezeit im südwesten der Iberischen Halbinsel. Madrider Forschungen 9. Berlín, Walter de Gruyter \& CO.

Servicio de Ordenación del Territorio (2015): Dominios paisajísticos de las tierras del gran lago de Alqueva. Badajoz. Mérida, Consejería de Fomento, Gobierno de Extremadura: http://www.ideextremadura.es/ficheros/Paisaje/tipos/ [06/02/2017].

Torres Ortiz, M. (2012): “La Precolonización en Extremadura”, en J. Jiménez Ávila (ed.), Sidereum Ana II. El río Guadiana en el Bronce Final. Anejos de Archivo Español de Arqueología 42: 455-474. Mérida, IAM-CSIC.

Uckelmann, M. (2011) "The function of Bronze Age shields", en M. Uckelmann y M. Mödlinger (eds.), Warfare in Bronze Age Europe: Manufacture and Use of Weaponry. BAR International Series 2255: 187-199. Oxford, Archaeopress.

Uckelmann, M. (2012): Die Schilde der Bronzezeit in Nord-, West- und Zentraleuropa. Prähistorische Bronzefunde III, 4. Stuttgart, Franz Steiner Verlag. Vaquerizo Gil, D. (1989): "La estela de Quinterías". Revista de Arqueología 99: 29-38. 